\title{
Análise de classes
}

\author{
Class analysis
}

A pesquisa empírica contida no livro Class counts: comparative studies in class analysis abrange uma ampla gama de temas substantivos: de padrões de amizade e mobilidade de classe a trabalho doméstico e consciência de classe. $O$ que une os temas não é uma preocupação com um objeto comum de explicação, e sim um fator explicativo comum: classe. É isso que a análise de classes tenta fazer: explorar a relação entre classe e todos os tipos de fenômenos sociais. Isso não significa, é claro, que a classe tenha importância explicativa para tudo. $\mathrm{Na}$ verdade, como vemos em algumas das análises do livro, ela acaba não se revelando um fator particularmente poderoso. A análise de classes não implica um compromisso com a tese de que todos os fenômenos sociais podem ser explicados principalmente em termos de classe, nem mesmo de que a classe é sempre um fator determinante. Em vez disso, a análise de classes se baseia na conviç̧ão de que a classe é uma causa social generalizada e, portanto, vale a pena explorar suas ramificações em muitos fenômenos sociais. Isso implica aprofundar nossa compreensão sobre os limites do que a classe pode explicar, bem como dos processos pelos quais ela ajuda a determinar aquilo que explica.

Assim entendida, a análise de classes é o que se poderia chamar de especialidade com "variável independente". É uma disciplina como a endo-

* É professor da University of Wisconsin (Madison, WI, Estados Unidos).

Publicado como capítulo 1 do livro Class counts: comparative studies in class analysis (Cambridge: Cambridge University Press, 1997). Direitos concedidos pela Cambridge University Press. Traduzido por Roberto Cataldo Costa. Revisão técnica da tradução por Luis Felipe Miguel. 
crinologia na medicina. Se você é endocrinologista, pode estudar um vasto leque de problemas - sexualidade, personalidade, crescimento, processos de adoecimento etc. - além do funcionamento interno do sistema endócrino, desde que explore a relação entre esse sistema e as questões a ser explicadas. A endocrinologia é monogâmica em sua variável explicativa - o sistema hormonal - mas promíscua em suas variáveis dependentes. Além disso, em endocrinologia, não é constrangedor descobrir que, para alguns problemas sob investigação, os hormônios acabam não sendo muito importantes. É um avanço em nosso conhecimento sobre endocrinologia saber o que os hormônios não explicam, assim como saber o que eles explicam. A oncologia, por sua vez, é uma disciplina com variáveis dependentes. Na condição de oncologista, você pode estudar qualquer causa imaginável de câncer - toxinas, genética, vírus, até mesmo estados psicológicos. A oncologia é monogâmica em sua variável dependente, mas promíscua em suas variáveis independentes. E, em oncologia, não é constrangedor descobrir que certas causas potenciais de câncer acabam não sendo muito importantes.

O referencial teórico mais aprimorado e sistemático para a análise de classes é encontrado na tradição marxista. Independentemente do que se possa pensar sobre sua adequação científica, o marxismo clássico é um projeto teórico ambicioso e elegante, no qual se considerou que a análise de classes proporcionaria as explicações mais fundamentais daquilo que se pode chamar de trajetória épica da história humana. $\mathrm{O}$ aforismo "a luta de classes é o motor da história" capta essa ideia. Com efeito, a teoria marxista da história - ou o que se costuma chamar de "materialismo histórico" - é como uma teoria médica que combinasse endocrinologia e oncologia ao afirmar que os mecanismos hormonais fornecem as explicações centrais ("o motor") para o desenvolvimento dinâmico ("a história”) dos cânceres. O argumento do materialismo histórico clássico nunca foi o de que tudo o que acontece na história poderia ser explicado pela análise de classes, embora muitos críticos do marxismo tenham acusado os marxistas de propor essa teoria monocausal. A afirmação é mais restrita, mas, ainda assim, ambiciosa: de que a trajetória geral do desenvolvimento histórico pode ser explicada por uma análise de classes bem construída. ${ }^{1}$

É desnecessário dizer que, assim como em todos os aspectos do marxismo, há muita disputa em relação ao grau de determinismo implícito na análise de classes dentro do materialismo histórico. Algumas pessoas argumentam que Marx jamais foi um determinista econômico; outras argumentam 
Muitos acadêmicos marxistas contemporâneos, talvez a maioria deles, recuaram em relação a essas afirmações grandiosas do materialismo histórico ortodoxo. Embora a ideia de que a história tem uma estrutura compreensível e de que as dinâmicas do capitalismo estão repletas de contradições que apontam na direção de um futuro socialista possa fazer parte do pano de fundo intelectual para os estudos marxistas, são postas de lado pela maioria das pesquisas reais que, em seu lugar, concentra-se nas formas pelas quais a classe afeta vários aspectos da vida social. A análise de classes, portanto, torna-se o núcleo de uma ampla agenda de pesquisa sobre as causas e as consequências das relações de classe.

É claro que a análise de classes de inspiração marxista não é a única forma de se estudar classe. Há, também, a análise de classes de inspiração weberiana, a análise de classes inspirada na estratificação, a análise de classes eclética, de senso comum. Portanto, precisamos esclarecer os contornos básicos do conceito de classe que será usado nas análises. Especificamente, é preciso esclarecer o conceito de estrutura de classes, uma vez que ele cumpre um papel central na análise de classes. Esse é o objetivo básico deste texto.

O conceito de "estrutura de classes" é apenas um elemento da análise de classes. Outros elementos conceituais são a formação de classes (a formação das classes até se tornarem atores coletivamente organizados), a luta de classes (as práticas de atores para a concretização de interesses de classe) e a consciência de classe (a compreensão, pelos atores, de seus interesses de classe). A tarefa da análise de classes não é apenas entender a estrutura de classes e seus efeitos, mas entender as interconexões entre todos esses elementos e suas consequências para outros aspectos da vida social.

No capítulo 13 de Class counts, exploraremos um modelo geral das interconexões entre esses elementos. A discussão aqui ficará restrita ao problema da estrutura de classes. Isso não se deve ao fato de eu acreditar que a estrutura de classes é sempre o princípio explicativo mais importante dentro da análise de classes. Por exemplo, a variação em formações de

que ele defendeu uma forma específica de determinismo econômico e de classe, que se baseava em pressupostos da ação humana. De qualquer forma, sendo determinista ou não, a análise de classes está no cerne das explicações das trajetórias históricas épicas em Marx. Para a visão mais sofisticada e profunda do materialismo histórico como teoria explicativa séria, ver G. A. Cohen (1978). Para alguns esclarecimentos importantes e aperfeiçoamentos dos argumentos contidos neste livro [Class counts: comparative studies in class analysis], ver Cohen (1988). Para uma avaliação geral das afirmações do materialismo histórico e das perspectivas de sua reconstrução, ver Wright, Levine e Sober (1992). 
classes em termos de tempo e lugar nas sociedades capitalistas certamente poderia ser um determinante mais significativo das variações nas políticas de Estado do que as variações nas estruturas de classes associadas a essas formações de classe. Em vez disso, trato inicialmente da estrutura de classes porque ela permanece conceitualmente fundamental para esclarecer a lógica geral da análise de classes. Falar de formação de classes ou luta de classes em vez de simplesmente formação ou luta coletiva implica que tenhamos uma definição de "classe" e saibamos o que significa descrever um ator coletivo como um caso de formação de classes, ou um conflito como um conflito de classes e não de um outro tipo. Aqui, a premissa é a de que o conceito de estrutura de classes transmite o conteúdo essencial da adjetivação "de classe" quando esta é atribuída a "formação", "consciência" e "luta”. A formação de classes é a formação de atores coletivos organizados em torno de interesses de classe, dentro de estruturas de classe; a luta de classes é a luta entre esses atores coletivamente organizados por interesses de classe; consciência de classe é a compreensão, por pessoas dentro de uma classe, de seus interesses de classe. Em cada caso é preciso já ter uma definição de estrutura de classes antes de poder especificar totalmente os outros conceitos. Elaborar um conceito coerente dessa estrutura é, portanto, uma precondição conceptual importante para se desenvolver uma teoria satisfatória sobre a relação entre estrutura de classe, formação de classes e luta de classes.

\section{A parábola do shmoo}

Uma história em quadrinhos de Li'l Abner², do fim da década de 1940 vai ajudar a preparar o terreno para discutirmos o conceito de estrutura de classes $^{3}$. Esta é a situação do episódio: Li'l Abner, morador da comunidade caipira de Dogpatch, descobre uma criatura estranha e maravilhosa, o "shmoo", e volta com um rebanho delas à comunidade. O único desejo do shmoo na vida é agradar aos seres humanos, transformando-se em coisas materiais de que eles precisam. Ele não dá luxos às pessoas, apenas as necessidades

No Brasil, Li'l Abner fez sucesso a partir dos anos 1940, com o nome de Ferdinando ou Família Buscapé, e a cidadezinha de Dogpatch tornou-se Brejo Seco. Como aquelas traduções estão há muito esgotadas e é mais provável que o leitor de hoje tome contato com a tira em inglês, mantivemos os nomes próprios originais. [N. do R. T.]

O uso desses episódios de Li'l Abner como ilustração da crítica moral ao capitalismo me foi apresentado pelo filósofo britânico G. A. Cohen em uma palestra para a televisão britânica em agosto de 1986. 
básicas da vida. Se você está com fome, os shmoos podem se transformar em presunto e ovos, mas não em caviar. Além do mais, multiplicam-se rapidamente para que você nunca fique sem eles. Sendo assim, eles têm pouco valor para os ricos, mas muito para os pobres. Com efeito, o shmoo devolve a humanidade ao Jardim do Éden. Quando Deus expulsou Adão e Eva do Paraíso por seus pecados, uma de suas punições mais severas foi a de que, a partir de então, eles e seus descendentes seriam forçados a "ganhar o pão com o suor do seu rosto". O shmoo alivia as pessoas dessa necessidade e, assim, atende a uma profunda fantasia na cultura ocidental.

No episódio de Li'l Abner reproduzido a seguir, um gerente que trabalha para um capitalista rico, P. U., faz um estudo para identificar o lugar mais pobre dos Estados Unidos, a fim de contratar a força de trabalho mais barata para uma nova fábrica. O lugar acaba sendo Dogpatch. P. U. e o gerente vão a Dogpatch para recrutar empregados para a nova fábrica. A narrativa se desenrola em uma sequência de histórias em quadrinhos a partir de 1948 (Al Capp, 1992, p. 134-6):
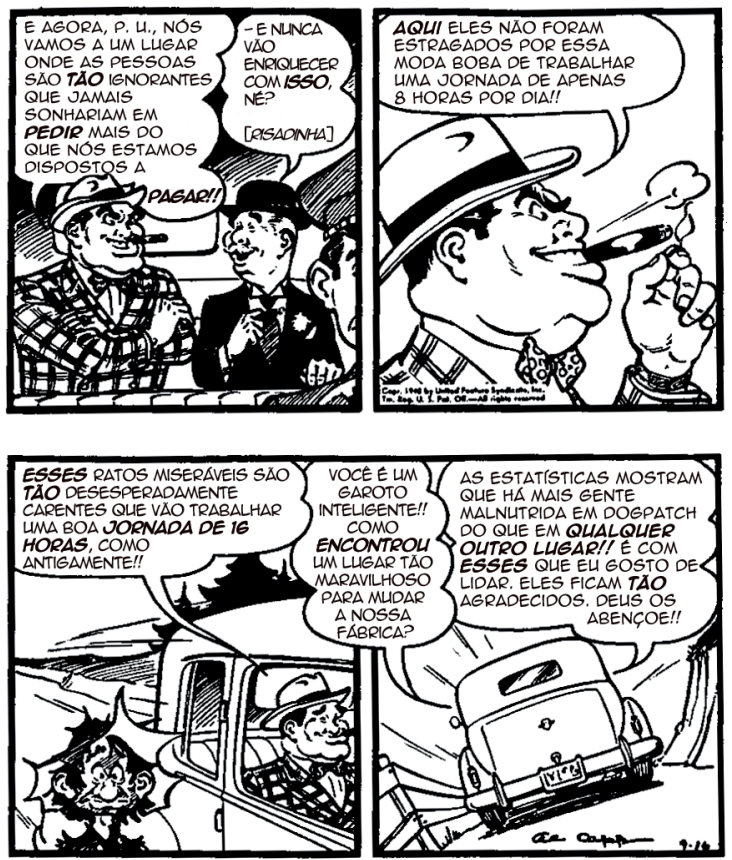

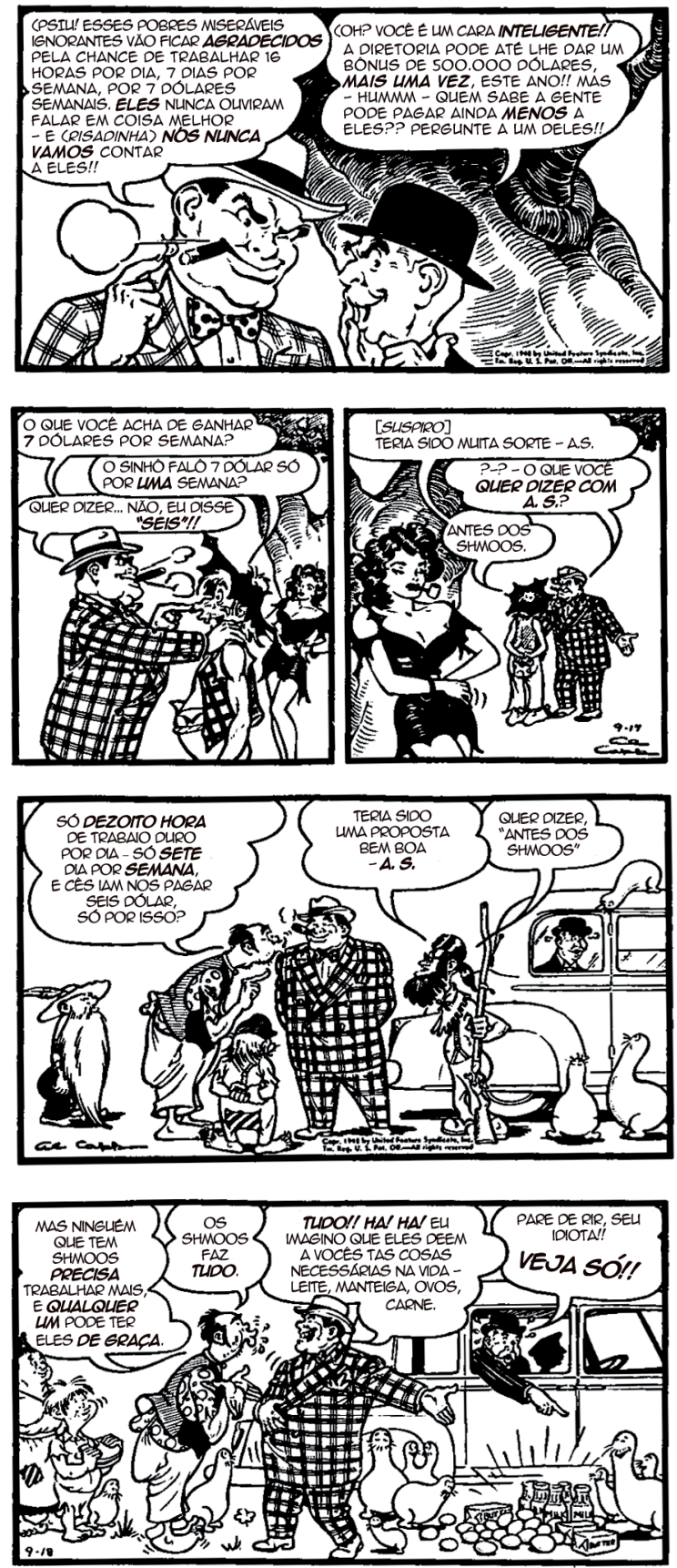

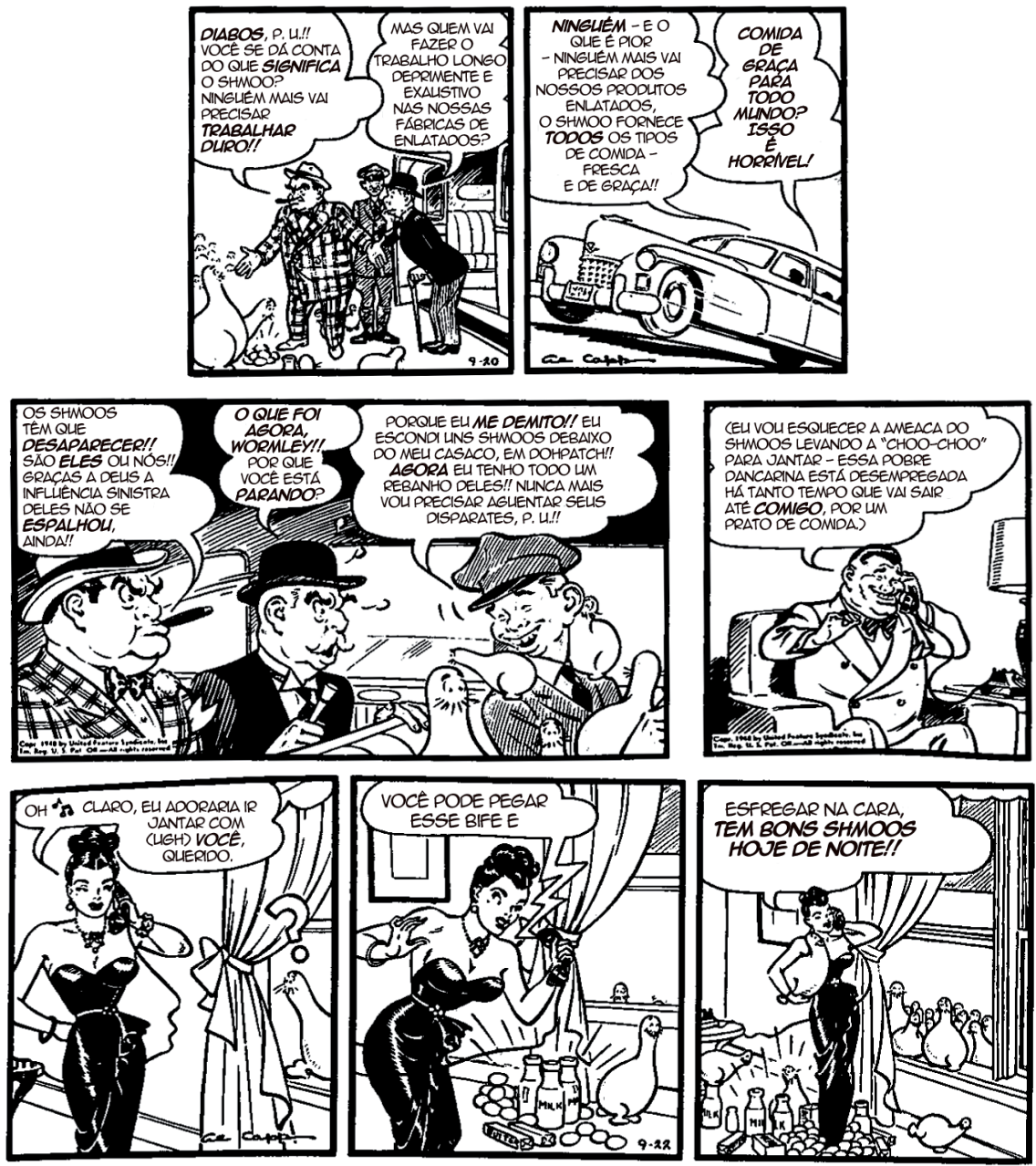

Portanto, a presença dos shmoos é uma grave ameaça às relações de classe e às relações de gênero. Ficou mais difícil recrutar trabalhadores para o trabalho penoso, e eles já não têm que aceitar os "disparates" e as indignidades a que seus patrões os submetem. As mulheres já não são dependem do dinheiro dos homens e, portanto, não precisam tolerar um tratamento sexista .

Considerando-se as ideologias dominantes da época, é impressionante que Al Capp tenha apontado as implicações do shmoo para a dominação de gênero. Afinal de contas, as implicações para os trabalhadores se encaixavam bem nos argumentos teóricos do marxismo que, na década de 1940, eram bastante conhecidos de muitos intelectuais. A crítica feminista à dominação masculina era muito menos conhecida. 
Nos episódios seguintes, P. U. e seu capanga organizam uma campanha para destruir os shmoos. Eles têm bastante êxito, e conseguem deter a influência sinistra da criatura. O capitalismo dos Estados Unidos pode continuar sem ser ameaçado pelo espectro do Jardim do Éden.

A saga do shmoo ajuda a esclarecer o sentido no qual os interesses dos trabalhadores e dos capitalistas são tão profundamente antagônicos - uma das ideias centrais da análise de classes marxista. Como os shmoos afetam os interesses materiais das pessoas nessas duas classes? ${ }^{5}$ Isso depende do nível de generosidade do shmoo, como indicado no Gráfico 1.

Gráfico 1 - Como shmoos de diferentes capacidades afetam os interesses dos trabalhadores e capitalistas

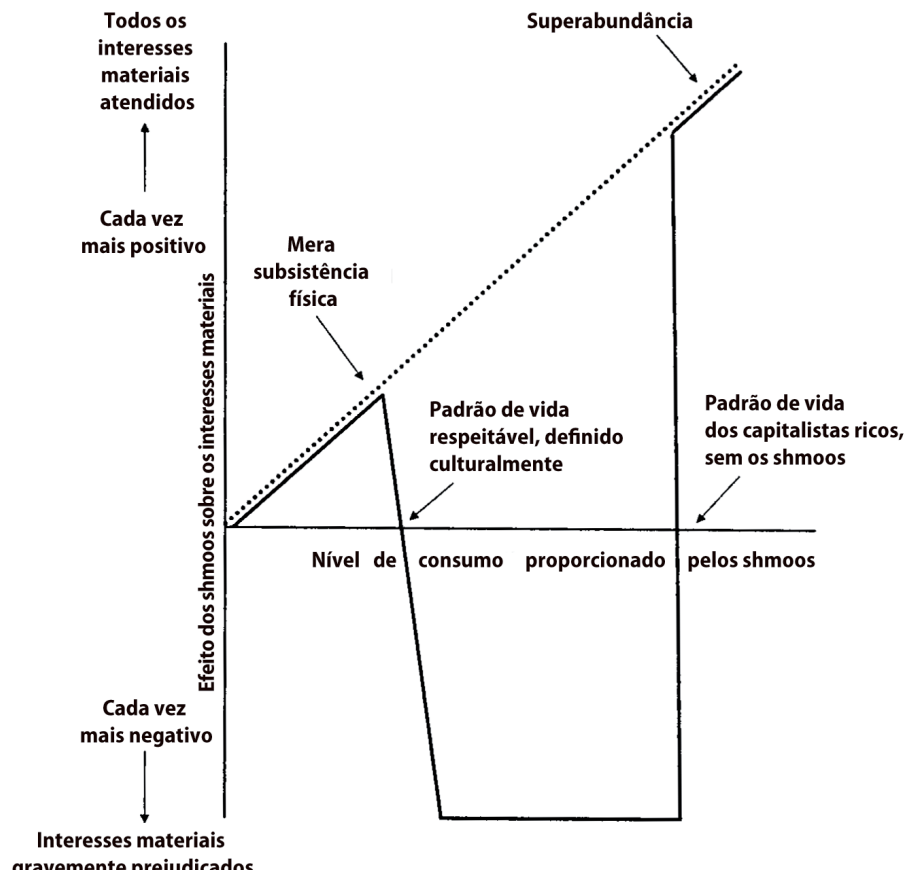

Com a expressão "interesses materiais" refiro-me aos interesses que as pessoas têm em seu padrão de vida material, entendido como o pacote que inclui labuta, consumo e lazer. Os interesses materiais não são, portanto, os interesses em maximizar o consumo em si, e sim interesses nas compensações entre labuta, lazer e consumo. Os interesses materiais, como discutirei aqui, também excluem bens puramente relacionados com status - bens que adquirem seu valor estritamente pelo fato de ser apreciados por poucas pessoas. Se os interesses dos capitalistas não fossem simplesmente ter padrões 
Se fornece menos do que o necessário à subsistência física, o shmoo provavelmente tem um efeito positivo sobre os interesses materiais de trabalhadores e capitalistas. Para os trabalhadores, ele torna suas vidas um pouco menos precárias; para os capitalistas, esses shmoos abaixo da subsistência poderiam ser considerados um subsídio aos salários. Mantidas as demais condições, os capitalistas poderiam pagar salários mais baixos se parte da subsistência dos trabalhadores fosse garantida fora do mercado ${ }^{6}$. No outro extremo, se os shmoos proporcionarem superabundância, atendendo a cada desejo material dos seres humanos - das necessidades básicas aos mais caros luxos - eles também atenderiam positivamente aos interesses materiais dos capitalistas. Entre esses dois extremos, contudo, o impacto do shmoo sobre os interesses materiais das duas classes é diferente. O bem-estar dos trabalhadores melhora continuamente conforme aumenta a generosidade dos shmoos, ao passo que, para os capitalistas, depois de certo tempo, seus interesses materiais são prejudicados. Se os shmoos fornecessem aos trabalhadores um padrão de vida respeitável, estes já não precisariam trabalhar para ter um padrão de vida aceitável. Como diz, em pânico, o gerente de $\mathrm{P}$. U.: "Você se dá conta do que significa o shmoo? Ninguém mais vai precisar trabalhar duro!!” Isso não significa, é claro, que nenhum trabalhador estaria disposto a trabalhar para um empregador. $\mathrm{O}$ trabalho atende a muitas necessidades das pessoas além de proporcionar rendimentos e, de qualquer forma, desde que o shmoo não ofereça superabundância, muitas pessoas vão ter desejos de consumo para além do nível fornecido por ele. No entanto, os trabalhadores estariam em uma posição muito mais forte para negociar tendo shmoos modestamente generosos em casa, e seria mais difícil, nas palavras de P. U., levá-los a "fazer o trabalho longo, deprimente e exaustivo em nossas fábricas de enlatados”.

materiais de vida elevados, mas ter padrões de vida mais elevados do que os outros para ter um status mais elevado, eles se oporiam aos shmoos mesmo que estes fornecessem às pessoas qualquer luxo imaginável. Também estou excluindo dos "interesses materiais" coisas como o desejo de dominação por si só. Sendo assim, interesses materiais são apenas aqueles que as pessoas têm em seu próprio padrão de vida. Para um estudo mais aprofundado sobre esse problema, ver Wright (1989, p. 280-8).

As donas de casa podem ser consideradas uma espécie de shmoo que fornece bens "gratuitos"em um nível abaixo da subsistência (já que a família de um trabalhador não consegue viver exclusivamente no trabalho da dona de casa).

Existe uma diferença interessante na análise do efeito do shmoo apresentada pelo morador de Dogpatch e pelo gerente de P. U. O morador proclama:"Mas ninguém que tem shmoos precisa trabalhar mais, e qualquer um pode tê-los de graça". Enquanto isso, o gerente declara:"Ninguém mais vai precisar trabalhar duro". O gerente entende que a questão é a extração do esforço de trabalho - a explora- 
Como resultado dessas diferenças do impacto do shmoo sobre os interesses materiais de trabalhadores e capitalistas, as pessoas situadas nessas duas classes têm preferências diferentes com relação ao destino do shmoo. Consideremos quatro possíveis distribuições de shmoos modestamente generosos: todo mundo recebe um shmoo; apenas os capitalistas recebem shmoos; apenas os trabalhadores recebem shmoos; os shmoos são destruídos para que ninguém os receba. O Quadro 1 indica as ordens de preferência para o destino de shmoos modestamente generosos com base na premissa de que trabalhadores e capitalistas sejam racionais e só estejam interessados em seu próprio bem-estar material ${ }^{8}$, portanto, que não sejam altruístas nem maliciosos. Para os capitalistas, sua primeira preferência é que só eles obtenham shmoos, uma vez que, obviamente, estariam um pouco melhor com shmoos do que sem eles.

Quadro 1 - Ordem de preferências para o destino do shmoo por posição de classe

\begin{tabular}{c|c|c}
\hline ordem & classe capitalista & classe trabalhadora \\
\hline 1 & Só os capitalistas recebem shmoos & Todo mundo recebe shmoos \\
\hline 2 & Os shmoos são destruídos & Apenas os trabalhadores recebem shmoos \\
\hline 3 & Todo mundo recebe shmoos & Só os capitalistas recebem shmoos \\
\hline 4 & Apenas os trabalhadores recebem shmoos & 0s shmoos são destruídos \\
\hline
\end{tabular}

Sua segunda preferência é que ninguém os receba. Eles preferem que os shmoos sejam destruídos a que cada pessoa receba um deles. Para os trabalhadores, ao contrário, sua primeira preferência é que todos recebam shmoos. Os trabalhadores ficarão em situação um pouco melhor se os capitalistas tiverem shmoos, assim como eles próprios, uma vez que isso significa que os capitalistas terão um pouco de mais dinheiro disponível para investir (porque não terão que pagar por suas necessidades básicas). A segunda preferência dos trabalhadores é que só eles recebam shmoos, a

ção - e não apenas fazer as pessoas virem "trabalhar". O morador só identifica um efeito no mercado de trabalho; o gerente identifica um efeito sobre o processo de trabalho. Em termos sociológicos, o morador faz uma análise weberiana e o gerente, uma análise marxista.

8 Essas ordens de preferência também pressupõem atributos homogêneos entre capitalistas e trabalhadores. Se há grandes capitalistas e pequenos capitalistas ou trabalhadores qualificados e trabalhadores não qualificados, as ordens de preferência podem ficar muito mais complicadas. Trabalhadores altamente qualificados, por exemplo, podem se beneficiar mais de uma oferta de bens baratos produzidos por trabalhadores não qualificados sem shmoos do que de um padrão de vida melhor com shmoos. 
terceira é que apenas os capitalistas os recebam, e sua última alternativa é que os shmoos sejam destruídos.

A ordem de preferência dos trabalhadores corresponde ao que poderia ser considerado interesses humanos universais. Essa é uma forma de entender a ideia marxista clássica de que a classe trabalhadora é a "classe universal": aquela cujos interesses materiais são equivalentes aos interesses da humanidade como tal. Essa ordem de preferências também corresponde ao que se poderia chamar de preferências rawlsianas - as que maximizam o bem-estar dos mais desfavorecidos em uma sociedade. Com relação ao shmoo, pelo menos, os interesses materiais dos trabalhadores correspondem aos ditames dos princípios rawlsianos de Justiça.

O que a história do shmoo ilustra é que as privações dos que nada possuem em um sistema capitalista não são simplesmente um subproduto infeliz da busca capitalista pelo lucro; elas são uma condição necessária dessa busca. É isso que significa afirmar que os lucros capitalistas dependem da "exploração" plorados adquiram os meios de subsistência, mesmo que, como no caso da história do shmoo, essa aquisição não assuma a forma de redistribuição da riqueza ou renda dos capitalistas aos trabalhadores. Dito de forma crua, o capitalismo gera um conjunto de incentivos tal que a classe capitalista tem interesse em destruir o Jardim do Éden.

Embora, no capitalismo real, os capitalistas não enfrentem o problema de uma ameaça dos shmoos, há episódios na história do capitalismo em que eles enfrentam obstáculos não tão diferentes. Os camponeses que trabalham pela subsistência têm uma espécie de shmoo na propriedade de suas terras férteis. Ainda que precisem trabalhar para se sustentar, eles não têm que trabalhar para os capitalistas. Em algumas épocas e lugares, os capitalistas adotaram estratégias deliberadas para reduzir a capacidade desses camponeses de viver da terra, especificamente para recrutá-los como força de trabalho. Um bom exemplo é o uso de impostos cobrados sobre as residências (hut taxes), em dinheiro, na África do Sul do século XIX, cujo objetivo era forçar esses camponeses a entrar no mercado de trabalho e trabalhar nas minas, obtendo dinheiro para pagar

Isso não implica que o nível de exploração seja o único determinante do nível de lucro, ou mesmo que os lucros sejam exclusivamente "derivados" da exploração. O que se está afirmando é que a exploração é uma das condições necessárias para o lucro em uma economia capitalista. 
seus impostos. De modo mais geral, os interesses capitalistas se opõem a arranjos sociais que tenham um caráter parcial sequer semelhante ao do shmoo. Sendo assim, os interesses da classe capitalista se opõem a coisas como renda básica universal garantida ou índices de desemprego duradouros muito baixos, mesmo que os impostos para sustentar esses programas sejam pagos integralmente pelos salários e, portanto, não saiam diretamente de seus próprios bolsos ${ }^{10}$. Isso reflete o sentido no qual a exploração capitalista gera interesses fundamentalmente antagônicos entre trabalhadores e capitalistas.

\section{O conceito de exploração}

A história do shmoo gira em torno das ligações entre divisões de classe, interesses de classe e exploração. Existem duas classes principais na história - os capitalistas, que possuem os meios de produção, e os trabalhadores, que não os possuem. Em virtude dos ativos produtivos que possuem (capital e força de trabalho), cada uma enfrenta um conjunto de restrições sobre como melhor ir em busca de seus interesses materiais. A presença de shmoos transforma fundamentalmente essas restrições e é uma ameaça aos interesses materiais dos capitalistas. Por quê? Porque prejudica sua capacidade de explorar a força de trabalho dos trabalhadores. "Exploração", portanto, é o conceito central para entender a natureza dos interesses gerados pelas relações de classe.

Exploração é um termo teórico complexo, uma vez que sugere uma condenação moral de determinadas relações e práticas, e não meramente uma descrição analítica. Descrever uma relação social como baseada em exploração é condená-la por ser tanto nociva quanto injusta para com os explorados. No entanto, embora essa dimensão moral da exploração seja importante, o cerne do conceito gira em torno de um determinado tipo de interdependência antagônica dos interesses materiais dos atores dentro das relações econômicas, e não da injustiça dessas relações como tais. Da forma como usarei a expressão, a exploração de classe é definida por três critérios principais:

${ }_{10}$ Isso não significa, é claro, que os capitalistas, como pessoas, não possam ser apoiadores entusiasmados dos shmoos e de políticas sociais do tipo shmoo. Afinal, Engels era um capitalista rico e era entusiasta de Marx e do socialismo revolucionário. Porém, ao apoiar shmoos ou o socialismo, os capitalistas estão agindo contra os seus interesses de classe. 
a) O bem-estar material de um grupo de pessoas depende causalmente das carências materiais de outro.

b) A relação causal em (a) envolve a exclusão assimétrica dos explorados em relação ao acesso a determinados recursos produtivos. Normalmente, essa exclusão é apoiada pela força, na forma de direitos de propriedade, mas pode não ser em casos especiais ${ }^{11}$.

c) O mecanismo causal que traduz exclusão (b) em bem-estar diferenciado (a) envolve a apropriação dos frutos do trabalho dos explorados por aqueles que controlam os recursos produtivos relevantes ${ }^{12}$.

Este é um conjunto bastante complexo de condições. A condição (a) estabelece o antagonismo dos interesses materiais. A condição (b) estabelece que esse antagonismo está enraizado no modo como as pessoas estão situadas dentro da organização social da produção. O termo "assimétrica", nesse critério, pretende excluir a "concorrência leal" do domínio de possíveis explorações. A condição (c) estabelece o mecanismo específico através do qual são gerados os interesses materiais, antagônicos interdependentes. O bem-estar do explorador depende do esforço dos explorados, e não apenas das privações destes ${ }^{13}$.

11 Um exemplo de exclusão em relação a recursos produtivos que não é apoiada pela força, mas que, no entanto, poderia ser a base para a exploração é a distribuição desigual de talentos. Embora se possa estender a noção de exclusão "coercitiva" para que inclua talentos (uma vez que as pessoas não talentosas são coercitivamente proibidas de possuir as talentosas como escravos), no funcionamento real das sociedades capitalistas a exclusão relevante não é garantida principalmente pela força.

12 A expressão "apropriação dos frutos do trabalho" se refere à apropriação daquilo que o trabalho produz. Ela não sugere que o valor desses produtos seja exclusivamente determinado pelo esforço de trabalho, como se afirma na teoria do valor-trabalho. Tudo o que se está afirmando aqui é que um excedente é apropriado - um excedente além do que é necessário para reproduzir todos os insumos da produção - e que esse excedente é produzido por meio de um esforço de trabalho, mas não que a medida adequada ao excedente seja o tempo de trabalho. Para uma discussão sobre essa forma de compreender a apropriação dos frutos do trabalho, ver Cohen (1988, 209-38).

13 Há situações em que as condições (a) e (c) estão presentes, mas não a condição (b). Por exemplo, no que às vezes é chamado de "modo tributário de produção", um aparato estatal centralizado e autoritário se apropria do excedente dos camponeses por meio de taxação, sem nenhum envolvimento direto na produção. Os camponeses certamente estão sendo explorados nessa situação, mas a elite do Estado não é uma "classe" de pleno direito, na medida em que sua posição social e seu poder não são determinados por sua posição dentro das relações sociais de produção. Poderíamos, talvez, estender um pouco o significado da condição (b), e tratar a apropriação direta de produtos dos camponeses por parte da elite do Estado como uma forma de "exclusão" dos camponeses em relação aos recursos produtivos (já que o próprio excedente é um recurso produtivo). Mas o principal mecanismo envolvido não está centrado nas relações sociais de produção, e sim no controle direto da violência por parte do Estado e, portanto, a elite do Estado não é uma "classe" no sentido padrão. 
Se apenas as duas primeiras dessas condições forem atendidas, teremos o que pode ser chamado de "opressão econômica não exploradora”, mas não “exploração". Na opressão econômica não exploradora, não há transferência dos frutos do trabalho dos oprimidos para os opressores; o bem-estar destes depende só da exclusão daqueles em relação ao acesso a determinados recursos, mas não de seu esforço. Em ambos os casos, as desigualdades em questão estão enraizadas na propriedade e no controle dos recursos produtivos.

A diferença crucial entre a exploração e a opressão não exploradora é que, em uma relação de exploração, o explorador precisa do explorado, já que depende de seu esforço. No caso da opressão não exploradora, os opressores ficariam felizes se os oprimidos simplesmente desaparecessem. A vida teria sido muito mais fácil para os colonizadores europeus na América do Norte se o continente não fosse habitado por pessoas ${ }^{14}$. O genocídio, portanto, é sempre uma estratégia em potencial para opressores não exploradores. Ele não é possível em uma situação de exploração econômica porque os exploradores precisam da força de trabalho dos explorados para seu bem-estar material. Não é por acaso que, culturalmente, temos o abominável ditado "índio bom é índio morto", mas não "trabalhador bom é trabalhador morto" ou "escravo bom é escravo morto". Faz sentido dizer que "trabalhador bom é trabalhador obediente e consciencioso", mas não que "trabalhador bom é trabalhador morto". O contraste entre a América do Norte e a África do Sul no tratamento dado aos povos indígenas reflete essa diferença de forma aguda: na América do Norte, onde os povos indígenas foram oprimidos (ao ser coercitivamente desalojados da terra), mas não explorados, o genocídio foi a política básica de controle social diante da resistência; na África do Sul, onde a população de colonizadores europeus dependia muito da força de trabalho africana para a sua própria prosperidade, isso não foi possível.

A exploração, portanto, não define apenas um conjunto de status dos atores sociais, mas um padrão de interações permanentes estruturado por um conjunto de relações sociais, as quais ligam mutuamente exploradores e explorados. Essa dependência do explorador em relação ao explorado dá a este uma certa forma de poder, já que os seres humanos sempre mantêm pelo menos um mínimo controle sobre o esforço que eles próprios fazem.

Isso não significa negar que, em certos casos específicos, os colonizadores se beneficiaram do conhecimento dos nativos, mas simplesmente afirmar o argumento de que a expulsão dos povos indígenas da terra foi um processo caro e problemático. 
O controle social do trabalho baseado exclusivamente na repressão é caro e, exceto em circunstâncias especiais, não costuma gerar níveis ideais de dedicação e esforço por parte dos explorados. Como resultado, geralmente há uma pressão sistemática sobre os exploradores para moderar sua dominação e, de uma forma ou de outra, tentar evocar algum grau de consentimento nos explorados, pelo menos no sentido de obter deles algum nível mínimo de cooperação. Sendo assim, talvez a exploração seja paradoxalmente uma força restritiva às práticas do explorador, e essa restrição constitua uma base de poder para os explorados.

Pessoas oprimidas, mas não exploradas, também podem ter algum poder, embora ele geralmente seja mais precário. No mínimo, os oprimidos têm o poder que vem da capacidade humana de resistência física. No entanto, como seus opressores não são economicamente obrigados a buscar algum tipo de cooperação da parte deles, o provável é que essa resistência cresça muito rapidamente e se transforme em confrontos bastante sangrentos e violentos. É por essa razão que a resistência dos indios norte-americanos a serem expulsos da terra fez com que fossem massacrados pelos colonizadores brancos. A pressão sobre os opressores não exploradores para que procurem soluções é muito fraca, e os resultados do conflito tendem a se tornar simplesmente uma questão de equilíbrio de força bruta entre inimigos. Quando os oprimidos também são explorados, mesmo que o explorador não sinta nenhum remorso moral, haverá restrições econômicas ao tratamento que ele dará ao explorado.

Descrever os interesses materiais de atores gerados pela exploração como antagônicos não prejudica o questionamento moral sobre a justiça ou injustiça das desigualdades geradas por esses antagonismos. Pode-se acreditar, por exemplo, que é moralmente justificado evitar que pessoas pobres nos países do terceiro mundo entrem livremente nos Estados Unidos e ainda reconhecer que existe um antagonismo objetivo de interesses materiais entre cidadãos norte-americanos e os candidatos a migrantes do Terceiro Mundo que são excluídos. Da mesma forma, reconhecer que o conflito entre capital e trabalho envolve interesses materiais antagônicos enraizados na apropriação do esforço de trabalho não implica necessariamente que os lucros capitalistas sejam injustos; significa apenas que eles são gerados em um contexto de conflito inerente.

No entanto, seria falso afirmar que o uso do termo "exploração" para designar essa forma de interdependência antagônica de interesses materiais 
é uma escolha estritamente científica e técnica. Descrever a apropriação do esforço de trabalho como "exploração" e não só como uma "transferência" acrescenta um severo julgamento moral à afirmação analítica. Sem pelo menos uma noção superficial do status moral da apropriação seria impossível, por exemplo, diferenciar coisas como tributação legítima e exploração. A primeira envolve apropriação coercitiva e, em muitos casos, pode-se dizer que há um conflito de interesses materiais entre as autoridades fiscais e o contribuinte como indivíduo privado. Mesmo em condições profundamente democráticas e igualitárias, muitas pessoas não pagariam impostos voluntariamente, já que prefeririam melhorar seus interesses materiais pessoais aproveitando-se dos impostos pagos por outras. Os libertários de direita, na verdade, consideram a tributação uma forma de exploração porque ela é uma violação da santidade do direito à propriedade privada e, portanto, uma apropriação injusta e coercitiva. O lema "tributação é roubo" equivale a "tributação é exploração". A alegação de que a apropriação capitalista do esforço de trabalho dos trabalhadores é "exploração", portanto, sugere algo mais do que um simples antagonismo de interesses materiais entre trabalhadores e capitalistas; ela sugere que essa apropriação é injusta.

Embora eu considere que se possa fazer uma boa defesa moral do tipo de igualitarismo radical que oferece um argumento para tratar a apropriação capitalista como injusta, seria demais, aqui, explorar as justificativas filosóficas dessa afirmação ${ }^{15}$. De qualquer forma, para fins de análise sociológica de classe, a questão crucial é o reconhecimento do antagonismo dos interesses materiais que estão ligados às relações de classe em virtude da apropriação do esforço de trabalho. Com base nisso, vou chamar tal apropriação de "exploração".

\section{Uma observação sobre a exploração como apropriação de excedente}

Até agora, nesta discussão, não se mencionou a ideia de exploração como apropriação de "excedente", a maneira tradicional como os marxistas formulam o conceito de "exploração". Às vezes, essa ideia é especificada em termos de excedente de trabalho; às vezes, como excedente de valor (mais-valia); e, às vezes, simplesmente como excedente de produção. Independentemente

Para uma discussão esclarecedora sobre os valores igualitários radicais, que fornece uma base para se considerarem as apropriações capitalistas como exploradoras, ver Cohen (1988, cap. 11). 
de qual dessas formulações se adote, a ideia parece bastante simples. O produto social total pode ser dividido em duas categorias amplas: uma parte é necessária para reproduzir todos os insumos usados na produção - força de trabalho (ou seja, a capacidade de trabalhar), matérias-primas, máquinas etc. A outra parte é um "excedente" - a quantidade do produto social para além dos custos de produção. Se esse excedente for apropriado por um grupo de pessoas que não aquelas que o produziram e essa apropriação não acontecer a mando dos produtores, estes serão geralmente considerados como "explorados".

A retórica da produção e da apropriação do excedente é atrativa para falar de exploração. A existência de um excedente social está intimamente ligada à acumulação de capital, e descrever a exploração em termos de excedente conecta, assim, a exploração a um aspecto central da dinâmica do capitalismo. A ideia de um excedente também tem uma qualidade física atraente, o que faz com que a apropriação do excedente pareça mais concreta do que a apropriação do esforço de trabalho.

Observando-se mais de perto, no entanto, o conceito de "excedente" não é tão simples. O problema básico está em apresentar um sentido claro para a expressão "os custos de produção e reprodução da força de trabalho", pois, a menos que esta ideia esteja clara, o conceito de "excedente" é ambíguo $^{16}$. Como deve ser definido? Uma solução apenas equipara o custo da força de trabalho a qualquer que seja o consumo empírico das pessoas (ou seja, o rendimento que elas recebem em um mercado de trabalho menos as economias que façam). $\mathrm{O}$ "excedente", então, seria simplesmente o valor do produto que sobra após o consumo pessoal e a substituição dos meios de produção ${ }^{17}$. Essa solução de definição, no entanto, afasta a possibilidade de que alguns assalariados possam se apropriar do excedente na forma de altos rendimentos e gastar tudo em um estilo de vida extravagante. Intuitivamente, parece razoável descrever o diretor-executivo de uma empresa, com salário

${ }^{16}$ Lembre-se de que "excedente" é o produto social total (medido de forma física ou de alguma outra maneira, como valor ou preço) menos o valor do produto necessário para (a) cobrir os custos dos meios de produção e matérias-primas usados na produção, e (b) cobrir os custos da reprodução da força de trabalho usada na produção. O primeiro desses custos de produção apresenta menos dificuldades conceituais do que o segundo.

17 O consumo dos capitalistas, desde que não sejam meramente rentistas, também deve ser excluído do excedente. Os capitalistas também podem trabalhar - eles fazem vários tipos de trabalho e, portanto, a reprodução de sua força de trabalho deve ser considerada como um "custo de produção". 
de um milhão de dólares por ano, como um explorador que se apropria de excedente dentro desse salário, independentemente de parte dessa renda ter sido economizada com consumo pessoal.

Uma alternativa é tratar os custos de produção/reprodução da força de trabalho apenas como custos de "subsistência básica", estabelecidos em algum padrão culturalmente apropriado, em vez de custos de todo o consumo empírico. Isso pode variar um pouco entre diferentes categorias de pessoas, já que certos tipos de força de trabalho podem exigir maior consumo para ser efetivamente produzidos e reproduzidos, mas o conceito ainda seria distinto dos rendimentos empíricos. Essa segunda estratégia tem a vantagem de não eliminar, por meio de definição, a possibilidade de que os altos salários possam ser uma fonte de exploração, mas tem a desvantagem de já não fornecer uma solução operacional clara para se distinguir o "excedente" dos "custos" da força de trabalho. Se fosse definida no âmbito da mera sobrevivência biológica, talvez a subsistência tivesse um significado inequívoco, mas, uma vez entendida como "subsistência básica estabelecida em algum nível culturalmente adequado", o conceito parece se tornar aberto e discricionário.

Uma maneira de resolver o problema é definir "subsistência básica" em termos contrafactuais. Imagine um mundo em que todas as pessoas que vendem sua força de trabalho tenham exatamente os mesmos dotes genéticos e socioeconômicos ${ }^{18}$. Ou seja, todas teriam uma capacidade igual de aprender e adquirir qualificações, todas teriam os mesmos recursos econômicos e todas enfrentariam as mesmas condições sociais. Nenhum trabalhador seria cultural nem socialmente desfavorecido em relação a outros. Todos teriam igual acesso a crédito para contrair empréstimos e obter formação avançada, e não haveria restrições institucionais ao acesso à formação. As faculdades de medicina, por exemplo, aceitariam qualquer candidato apto (e essas condições de aptidão, por sua vez, seriam acessíveis a todos com base na premissa de que todos receberam dotes iguais). Nessas condições, as pessoas escolheriam quanta formação obter com base na quantidade de esforço que quisessem fazer, dados os custos dos financiamentos e os rendimentos que poderiam esperar obter dessa formação. Como resultado, a variação dos rendimentos

\footnotetext{
18 A razão para postular dotes genéticos iguais é remover todos os impedimentos à aquisição de qualificações pelos trabalhadores, de modo que as diferenças de salários ligadas a qualificações entre as pessoas seriam simplesmente uma função das diferenças nos custos reais de aquisição e manutenção das qualificações. Se certas qualificações exigissem certos dotes genéticos especiais, e esses dotes são raros, não seria o caso.
} 
do mercado de trabalho entre diferentes profissões simplesmente refletiria os diferentes custos (incluindo o esforço) de adquirir as qualificações e executar as atividades da profissão. Nada haveria de moralmente censurável nas diferenças de rendimentos entre as profissões nessas circunstâncias. Se acontecesse de os níveis salariais de uma profissão estarem acima desses custos por causa de um déficit de oferta em algum tipo de força de trabalho, mais pessoas procurariam a formação adequada e, como resultado, os salários cairiam. Nesse mundo de concorrência perfeita nos mercados de trabalho e de capacidade irrestrita dos trabalhadores de adquirir qualificações, podemos definir "subsistência básica" como o salário de equilíbrio competitivo ${ }^{19}$.

É claro que não vivemos em um mundo assim e, por isso, as pressões que reduziriam os salários de todas as profissões a esse nível contrafactual são bloqueadas de várias maneiras. Em alguns casos, como na profissão médica nos Estados Unidos, há dotes institucionais deliberados (sociais, econômicos e genéticos), e as restrições ao acesso ao crédito significam que, para muitos empregos, os rendimentos não vão estar em equilíbrio com os custos de produção e reprodução da força de trabalho. Nesses casos, parte do excedente social é distribuída às pessoas na forma de rendimentos mais elevados ${ }^{20}$.

Devido à complexidade de se entender a ideia de "excedente" em termos de uma noção contrafactual de custos de produção determinados de forma competitiva, eu discutiria, de modo geral, a exploração em termos de extração e apropriação de esforço. Essa forma de enquadrar o conceito também destaca a ligação entre produção e troca, que está no centro da teoria da exploração. Haverá espaços, no entanto - como na discussão de "exploração de qualificações" -, onde a linguagem mais convencional de apropriação do excedente será conveniente. Quando eu falo sobre exploração nesses termos, portanto, o excedente deve ser entendido dessa maneira contrafactual.

${ }_{19}$ Nessa forma de definir"subsistência básica", uma combinação de melhorias na produtividade e lutas de classe poderia elevar o nível dos salários reais para todos os trabalhadores acima da mera subsistência biológica. O "excedente", contrafactualmente definido, portanto, é o excedente acima dos custos historicamente alcançados de produzir/reproduzir a força de trabalho sob a premissa de mercados de trabalho puramente competitivos.

20 Um problema semelhante pode ocorrer com relação aos custos de produção/reprodução dos meios de produção. Em condições de monopólio da produção de algum insumo físico à produção, o preço empírico daquele insumo será superior ao preço que esses insumos teriam tido sob condições de mercado competitivas. Esse "aluguel de monopólio" no preço é uma forma em que o vendedor do insumo em questão consegue se apropriar do excedente. Os preços empíricos dentro das relações de troca, portanto, podem constituir um mecanismo de apropriação e distribuição do excedente aos capitalistas, bem como a assalariados privilegiados. 


\section{Classe e exploração}

Na tradição marxista de análise de classes, as divisões de classe são definidas principalmente em termos da ligação entre as relações de propriedade e de exploração. Os senhores de escravos e os escravos constituem classes porque uma determinada relação de propriedade (direitos de propriedade sobre as pessoas) gera exploração (a apropriação dos frutos do trabalho do escravo pelo senhor de escravos). Proprietários de moradias e sem-teto não constituiriam "classes", embora sejam diferenciados em seus direitos de propriedade sobre habitação, já que essa divisão não constitui uma base para a exploração dos sem-teto pelos proprietários de moradias ${ }^{21}$.

Na sociedade capitalista, a forma central de exploração se baseia em direitos de propriedade sobre os meios de produção. Esses direitos de propriedade geram três classes básicas: os capitalistas (exploradores), que possuem os meios de produção e contratam trabalhadores; os trabalhadores (explorados), que não possuem os meios de produção e vendem sua força de trabalho aos capitalistas; e os pequeno-burgueses (nem exploradores nem explorados), que possuem e usam os meios de produção sem contratar outras pessoas ${ }^{22}$. A visão marxista de como a relação capital-trabalho gera exploração é conhecida: para adquirir seus meios de subsistência, os trabalhadores desprovidos de propriedades têm que vender sua força de trabalho a pessoas que possuam os meios de produção ${ }^{23}$. Nessa relação de troca, concordam em trabalhar por um período de tempo especificado por um salário que usam para comprar seus meios de subsistência. Por causa da relação de poder entre capitalistas e trabalhadores, aqueles conseguem obrigar estes a produzir mais do que é necessário para sua subsistência. Como resultado, os trabalhadores produzem

${ }_{21}$ Se os proprietários de moradias trocassem habitação em quartos vagos por serviço doméstico, os direitos de propriedade sobre a habitação poderiam se tornar a base para uma relação de classe. No entanto, o simples fato de haver propriedade de casas e pessoas sem ter onde morar não constitui, em si, uma forma de exploração e, portanto, não é uma divisão de classes. Somente quando esse direito de propriedade se traduz em uma relação de poder entre os atores na qual o trabalho é apropriado é que ela se torna de exploração.

${ }^{22}$ Como argumenta Roemer (1982), é possível que algum pequeno burguês seja explorado ou até explorador por meio de trocas desiguais no mercado. Um pequeno burguês que trabalhe com meios de produção com elevado uso de capital, por exemplo, pode conseguir se apropriar dos frutos do trabalho de outros por meio de troca.

${ }^{23}$ Para ser um pouco mais preciso, a fim de adquirir os meios de subsistência, pelo menos alguns membros de uma família sem propriedades (definida como a unidade de consumo compartilhado) devem vender força de trabalho a empregadores. Em alguns lugares e épocas, isso determinou que o homem provedor entrasse no mercado de trabalho e a mulher "dona de casa"ficasse no lar. No capitalismo contemporâneo avançado, em geral, todos os membros adultos das famílias vendem sua força de trabalho. 
um excedente que é de propriedade do capitalista e assume a forma de lucro. O lucro, a quantidade de produto social que sobra após terem sido deduzidos os custos de produção e reprodução de todos os insumos (insumos de força de trabalho e insumos físicos), constitui uma apropriação dos frutos do trabalho dos trabalhadores.

Descrever essa relação como exploradora é uma afirmação sobre a base para o conflito inerente entre trabalhadores e capitalistas na relação de emprego e aponta para o fato fundamental de que o conflito entre eles não se dá apenas pelo nível dos salários, mas pela quantidade de esforço de trabalho realizado para obter esses salários. Os capitalistas sempre querem que os trabalhadores façam mais esforço do que estão dispostos a fazer. Como argumentam Bowles e Gintis (1990), o nível de esforço dos trabalhadores do tipo "assobiando enquanto você trabalha" está sempre abaixo do ideal para os capitalistas e, assim, eles têm que adotar várias estratégias de vigilância e controle para aumentar o esforço de trabalho. Embora a intensidade do conflito aberto gerado por essas relações possa variar em épocas e lugares diferentes e possa haver compromissos de classe que incluam altos níveis de cooperação entre trabalhadores e gerentes, esse antagonismo subjacente de interesses materiais se manterá enquanto a relação permanecer baseada na exploração.

Para alguns propósitos teóricos e empíricos, essa imagem simples da estrutura de classe pode ser suficiente. Por exemplo, se o objetivo principal de uma análise for explorar as diferenças básicas entre as estruturas de classe do feudalismo e do capitalismo, uma análise que girasse inteiramente em torno da relação entre capitalistas e trabalhadores poderia ser adequada. Todavia, para muitas das coisas que queremos estudar com a análise de classes, precisamos de um conjunto mais matizado de categorias. Particularmente, precisamos de conceitos que possibilitem dois tipos de análises: primeiro, a análise da variação das estruturas de classe de sociedades capitalistas concretas em diferentes épocas e lugares; segundo, a análise das formas em que vidas individuais são afetadas por sua posição dentro da estrutura de classes. A primeira delas é necessária se quisermos explorar macrovariações de forma detalhada; a segunda é necessária se quisermos usar a classe de forma eficaz em microanálise ${ }^{24}$.

24 Para uma discussão mais ampla sobre as limitações do conceito abstrato excessivamente polarizado de estrutura de classes, ver Wright (1989a, p. 271-8). 
Ambas as tarefas envolvem a elaboração de um conceito de estrutura de classes nas sociedades capitalistas que vá além da polarização central entre capitalistas e trabalhadores. Mais especificamente, envolve resolver dois problemas gerais na análise estrutural de classes: em primeiro lugar, o problema de situar a "classe média" dentro da estrutura de classes e, em segundo, o de situar nessa estrutura de classe as pessoas não incluídas na força de trabalho remunerada ${ }^{25}$.

\section{O problema da "classe média" entre os empregados}

Se limitarmos a análise da estrutura de classes no capitalismo à propriedade dos meios de produção e à exclusão em relação a eles, vamos acabar com uma estrutura de classes em que existem apenas três posições - a classe capitalista, a classe trabalhadora e a pequena burguesia (aqueles que possuem os meios de produção, mas não contratam trabalhadores) - e na qual cerca de $85 \%$ a $90 \%$ da população, na maioria dos países capitalistas desenvolvidos, estão em uma única classe. Embora possa refletir de alguma forma uma verdade profunda sobre o capitalismo - a de que a grande maioria da população está separada dos meios de produção e precisa vender sua força de trabalho no mercado de trabalho para sobreviver - isso não nos oferece uma estrutura conceitual adequada para explicar muitas das coisas que queremos que a classe ajude a explicar. Especificamente, se queremos que a estrutura de classes ajude a explicar a consciência de classe, a formação de classes e o conflito de classes, precisamos de alguma maneira de entender as divisões dentro da população empregada.

Em linguagem comum, este é o problema da "classe média" - pessoas que não possuem seus próprios meios de produção, que vendem sua força de trabalho em um mercado de trabalho, mas, mesmo assim, não parecem fazer parte da "classe trabalhadora". Dessa forma, a questão é: em que base podemos diferenciar posições de classe entre as pessoas que compartilham uma posição comum de não proprietárias dentro das relações capitalistas de propriedade? Nas minhas análises, dividirei a classe dos trabalhadores segundo duas dimensões: em primeiro lugar, sua relação com a autoridade dentro da produção; em segundo, sua posse de qualificações ou especialização ${ }^{26}$.

${ }^{25}$ Há outros problemas na elaboração do conceito de estrutura de classes, que são discutidos em outros capítulos de Class counts. A posição dos empregados do Estado na estrutura de classes é discutida no capítulo 15. A questão da dimensão temporal das posições de classe - o fato de que alguns trabalhos são organizados dentro de carreiras que ultrapassam os limites de classe - é discutida nos capítulos 5 e 6.

${ }^{26}$ Esta discussão conceitual difere em vários aspectos da forma como eu abordei essas questões em 


\section{Autoridade}

Há dois argumentos para se tratar a autoridade como uma dimensão das relações de classe entre os empregados. A primeira diz respeito ao papel da dominação dentro das relações capitalistas de propriedade. Para assegurar que os trabalhadores façam o esforço adequado, a produção capitalista sempre envolve um aparato de dominação que inclui vigilância, sanções positivas e negativas, e várias formas de hierarquia. Os capitalistas não apenas possuem os meios de produção e contratam trabalhadores; eles também dominam os trabalhadores na produção.

Nesses termos, pode-se considerar que gerentes e supervisores exercem poderes de classe capitalistas delegados, na medida em que se envolvem em práticas de dominação dentro da produção. Nesse sentido, podem ser situados simultaneamente na classe capitalista $e$ na classe trabalhadora: eles são como os capitalistas, no sentido de que dominam os trabalhadores, e são como os trabalhadores, pois são controlados por capitalistas e explorados dentro da produção. Assim, ocupam o que chamei de posições contraditórias dentro das relações de classe. Usa-se nessa expressão o termo "contraditórias", em vez de simplesmente "duplas", porque os interesses de classe incorporados em cargos de gerência combinam os interesses inerentemente antagônicos de capital e trabalho. Quanto mais alguém sobe na hierarquia de autoridade, maior será o peso dos interesses capitalistas dentro dessa posição de classe. Portanto, gerentes de nível superior e, principalmente, diretores executivos de grandes empresas estarão muito intimamente ligados à classe capitalista, enquanto o caráter de classe dos cargos de chefia de nível inferior estará muito mais próximo ao da classe trabalhadora.

O segundo argumento para tratar a dimensão de autoridade como critério para diferenciar posições de classe entre empregados está centrado na relação entre os seus rendimentos e a apropriação do excedente. A localização estratégica dos gerentes na organização da produção lhes permite fazer algumas demandas significativas sobre uma parte do excedente social

meu livro anterior, Classes (Wright, 1985). Ali, argumentei que a fundamentação para que autoridade e qualificações fossem consideradas dimensões da estrutura de classes era de que o controle dos ativos de organização (ou seja, autoridade) e ativos de qualificação eram a base para formas diferentes de exploração. Por razões que abordei em um ensaio posterior (Wright, 1989, cap. 8), essa não parece ser mais uma maneira satisfatória de especificar o caráter de classe da "classe média". Embora não tenha a simetria da estratégia de análise anterior, acredito que a formulação apresentada aqui seja conceitualmente mais sólida. 
(definido da maneira contrafactual discutida acima), na forma de rendimentos relativamente elevados ${ }^{27}$. Com efeito, isso significa que os salários e as remunerações da força de trabalho gerencial estão acima dos custos de produção e reprodução de sua força de trabalho (incluindo quaisquer qualificações que possam ter).

O mecanismo específico pelo qual essa apropriação ocorre pode ser chamado de "aluguel de lealdade". É importante para a rentabilidade das empresas capitalistas que os gerentes exerçam seu poder de forma eficaz e responsável. A dificuldade é que um alto nível de vigilância e ameaças não costuma ser uma estratégia eficaz para evocar esse tipo de comportamento, seja porque o desempenho gerencial costuma ser muito difícil de monitorar, seja porque os controles repressivos tendem a prejudicar a iniciativa em vez de estimular o comportamento criativo. O que é necessário, então, é uma forma de gerar algum grau de compromisso real por parte dos gerentes para com os objetivos da organização. Isso é conseguido por meio de rendimentos relativamente elevados ligados às carreiras e às escadas de promoção dentro das hierarquias de autoridade. Estes rendimentos mais elevados envolvem uma redistribuição de parte do excedente social aos gerentes, a fim de fortalecer sua lealdade para com a organização. É claro que as sanções negativas ainda estão presentes como pano de fundo: os gerentes podem ser demitidos, disciplinados por mau trabalho, não obtendo promoções ou aumentos etc. Mas essas formas coercitivas de controle adquirem eficácia a partir de sua ligação com os fortes incentivos de rendimentos que, principalmente para gerentes de nível mais alto, estão muito acima dos custos de produção das qualificações desses gerentes ${ }^{28}$. Portanto, os gerentes não só ocupam posições

27 Em trabalhos anteriores, argumentei que, em virtude dessa apropriação do excedente, os gerentes devem ser considerados exploradores. O problema com essa formulação é que eles também contribuem para o excedente com sua própria atividade de trabalho e, portanto, sua renda excedente pode refletir a capacidade de se apropriar de parte dos excedentes que eles contribuem para produzir. Em vez de ser "exploradores", portanto, muitos gerentes podem simplesmente ser menos explorados do que outros empregados. Por causa dessa ambiguidade, é melhor considerar que os gerentes ocupam um lugar privilegiado no processo de exploração, que lhes permite se apropriar de parte do excedente social na forma de rendimentos mais elevados.

${ }^{28}$ Esse componente de aluguel nos salários dos gerentes já foi reconhecido na teoria do "salário de eficiência", que admite que o salário de equilíbrio de mercado pode estar abaixo do ideal do ponto de vista dos objetivos do empregador. Devido à dificuldade de fazer cumprir contratos de trabalho, os empregadores têm de pagar aos empregados mais do que os salários previstos pelas teorias de equilíbrio competitivo para obter complacência. Embora possa gerar alguns pequenos "aluguéis de emprego" para todos os funcionários, esse mecanismo é especialmente marcante para os que ocupam funções estratégicas que exigem um desempenho responsável e diligente de funções. Para 
contraditórias dentro das relações de classe, por força da dominação, mas também ocupam o que poderia ser chamado de uma posição de apropriação privilegiada dentro das relações de exploração. Ambas os diferenciam da classe trabalhadora.

\section{Qualificações e especialização}

O segundo eixo de diferenciação de classe entre empregados está centrado na posse de qualificações ou especialização. Assim como os gerentes, empregados que possuam altos níveis de qualificações/especialização estão potencialmente em posição privilegiada para a apropriação dentro das relações de exploração. Há dois mecanismos principais pelos quais isso pode acontecer.

Em primeiro lugar, qualificações e especialização costumam ser escassas no mercado de trabalho, não por estarem em falta, mas porque há obstáculos sistemáticos impedindo o aumento da oferta dessas qualificações para atender às necessidades das organizações empregadoras. Uma forma importante desses obstáculos é a dos diplomas, mas os talentos raros também poderiam constituir a base para as a manutenção das restrições na oferta de uma forma particular de força de trabalho ${ }^{29}$. O resultado dessas restrições à oferta é que os proprietários das qualificações escassas conseguem receber um salário acima dos custos de produção e reprodução da sua força de trabalho. Esse "aluguel de qualificações" é uma maneira de os empregados conseguirem se apropriar de parte do excedente social.

Em segundo lugar, o controle sobre o conhecimento e as qualificações também costuma dificultar o monitoramento e o controle do esforço de trabalho dos trabalhadores qualificados. O controle efetivo sobre o conhecimento por esses empregadores significa que os empregadores precisam depender, em certa medida, de mecanismos de reforço à lealdade para alcançar os níveis desejados de cooperação e esforço de funcionários com altos níveis de qua-

a discussão predominante em economia sobre salários de eficiência, ver Akerloff e Yellen (1986). Para argumentos que estendem a teoria do salário-eficiência aos argumentos marxistas sobre a "extração" do esforço de trabalho dos trabalhadores, ver Bowles e Gintis (1990).

29 Os diplomas não seriam uma restrição à oferta de um determinado tipo de qualificação se não houvesse obstáculos para os indivíduos os adquirirem. Há vários desses obstáculos: restrições ao número de vagas nos programas de formação, restrições nos mercados de crédito para empréstimos voltados à formação, desigualdade na distribuição de "capital cultural" (incluindo coisas como maneiras, sotaque, aparência etc.) e "capital social" (principalmente coisas como acesso a redes e informação), e, é claro, desigualdades nos dotes genéticos. 
lificações e especialização, assim como têm que fazer no caso dos gerentes. Empregados com elevados níveis de especialização conseguem se apropriar do excedente por causa de sua posição estratégica dentro da organização da produção (como controladores de conhecimento) e por causa de sua posição estratégica na organização dos mercados de trabalho (como controladores de uma forma escassa de força de trabalho).

Assim entendida, a posse de qualificações e especialização define uma posição diferenciada dentro das relações de classe por causa de um tipo específico de poder que confere aos empregados. Também pode ser o caso de que especialização, qualificações e conhecimentos estejam associados a vários tipos de "capital simbólico" e estilos diferenciados de vida, como observaram Bourdieu (1984) e outros. Embora possam ter considerável importância explicativa para várias questões sociológicas, esses correlatos culturais da classe não constituem o argumento essencial para tratar qualificações e especialização como uma dimensão da posição de classe dentro de uma análise de classes materialista (exceto na medida em que o capital simbólico cumpre um papel na aquisição de qualificações e diplomas). Esse argumento se baseia na afirmação de que os especialistas, assim como os gerentes, ocupam uma posição de apropriação privilegiada dentro das relações de exploração que os diferencia dos trabalhadores comuns.

Ao longo de Class counts, uso com frequência as palavras "qualificações e especialização" como um par. Por si só, o termo "qualificação" é usado, às vezes, simplesmente para designar qualificações manuais, em vez de a ideia mais geral de força de trabalho aprimorada ou complexa, diferente da força de trabalho "bruta" ou não desenvolvida. Esse aprimoramento pode assumir muitas formas, tanto físicas quanto cognitivas. Pode proporcionar uma grande flexibilidade para alguém se envolver em uma variedade de contextos de trabalho ou pode ser altamente especializado e vulnerável à obsolescência. A força de trabalho aprimorada costuma ser legalmente certificada na forma de diplomas oficiais, mas, em algumas circunstâncias, as qualificações e a especialização podem funcionar de forma eficaz sem essa certificação. A ideia teórica importante é que qualificações e especialização designam um ativo corporificado na força de trabalho das pessoas, que potencializa seu poder nos mercados de trabalho e nos processos de trabalho. 


\section{Um mapa de posições de classe da classe média}

Acrescentando-se o lugar ocupado dentro de hierarquias de autoridade e a posse de qualificações e especialização escassas à dimensão fundamental das relações capitalistas de propriedade, temos o mapa de posições de classe apresentado no Quadro 2. Com as devidas modificações, dependendo de nossos objetivos empíricos específicos, esse é o esquema básico que embasa minhas investigações. É importante ressaltar que este é um mapa das posições de classe. Os campos na tipologia não são "classes" propriamente ditas; são posições dentro das relações de classe. Alguns são posições contraditórias dentro das relações de classe; outros são posições de apropriação privilegiadas dentro das relações de exploração; outras, ainda, são posições polarizadas dentro das relações capitalistas de propriedade. Por convenção, as posições polarizadas "capitalistas" e "trabalhadores" no capitalismo - costumam ser chamadas de "classes", mas a terminologia mais precisa seria descrevê-las como posições fundamentais na estrutura de classe capitalista. A tipologia não é, portanto, uma proposta de modelo de seis classes para estrutura de classes do capitalismo, e sim um modelo de uma estrutura de classe que diferencia seis posições dentro das relações de classe.

Quadro 2: Tipologia de classe básica

relação com os meios de produção

\begin{tabular}{|c|c|c|c|c|c|}
\hline \multirow[b]{2}{*}{$\begin{array}{c}\text { contrata força } \\
\text { de trabalho }\end{array}$} & proprietário & \multicolumn{2}{|c|}{ empregados } & \multirow[b]{2}{*}{$\begin{array}{c}\text { exerce } \\
\text { autoridade }\end{array}$} & \multirow{3}{*}{$\begin{array}{l}\text { relação com } \\
\text { exercício de } \\
\text { autoridade }\end{array}$} \\
\hline & capitalistas & $\begin{array}{c}\text { gerentes } \\
\text { especializados }\end{array}$ & $\begin{array}{l}\text { gerentes não } \\
\text { especializados }\end{array}$ & & \\
\hline $\begin{array}{c}\text { não } \\
\text { contrata força } \\
\text { de trabalho }\end{array}$ & $\begin{array}{l}\text { pequenos- } \\
\text {-burgueses }\end{array}$ & especialistas & trabalhadores & $\begin{array}{c}\text { sem } \\
\text { autoridade }\end{array}$ & \\
\hline & & $\begin{array}{l}\text { possui qualifica- } \\
\text { ções escassas }\end{array}$ & $\begin{array}{c}\text { sem } \\
\text { qualificações }\end{array}$ & & \\
\hline
\end{tabular}

relação com qualificações 
Em algumas das análises empíricas que discutiremos, vamos combinar algumas das posições dessa tipologia, geralmente para gerar uma tipologia de quatro categorias, composta por capitalistas, pequeno-burgueses, posições "de classe média" (posições contraditórias e posições privilegiadas de apropriação entre os empregados) e trabalhadores. Em outras análises, modificaremos a tipologia ao acrescentar categorias intermediárias ao longo de cada uma das dimensões. Na relação com a dimensão dos meios de produção, isso envolve a distinção entre capitalistas de fato, pequenos empregadores que só têm uns poucos funcionários, e a pequena burguesia (autônomos sem empregados). $\mathrm{Na}$ dimensão de autoridade, significa diferenciar gerentes propriamente ditos - pessoas que estão envolvidas no processo organizacional de tomada de decisões - e meros supervisores, que têm poder sobre subordinados, mas não estão envolvidos em decisões sobre a formulação de políticas. E, na dimensão de qualificação, envolve a distinção entre profissões que normalmente demandam especializações acadêmicas e outras profissões qualificadas, que exigem níveis mais baixos de formação especializada. O resultado será a matriz de estrutura de classes de doze posições, apresentada no Quadro 3. Essa maneira de especificar o caráter diferenciado da posição de classe de gerentes e especialistas é semelhante, em alguns aspectos, ao tratamento dado por Goldthorpe (1982) ao conceito de "classe de serviços". Goldthorpe estabelece uma distinção entre dois tipos de relações de emprego: uma baseada em um contrato de trabalho, característica das classes trabalhadoras, e uma baseada no que ele chama de uma "relação de serviço", característica de gerentes e especialistas. Nesta última, os empregados entram em uma estrutura de carreira, e não só em um emprego, e suas recompensas se baseiam, em aspectos significativos, em perspectivas, em vez de simples pagamentos por trabalho realizado. Essa relação de serviço, argumenta Goldthorpe, tem "probabilidades de ser encontrada onde se exige dos empregados que exerçam autoridade delegada ou conhecimento especializado e especialização no interesse da organização que os emprega. Sendo assim ... seu desempenho dependerá do grau de compromisso moral que sentirem em relação à organização, e não da eficácia de sanções externas" (Erikson e Goldthorpe, 1993, p. 42). Essa caracterização está intimamente relacionada à ideia de que a cooperação de empregados de classe média, em função de seu poder estratégico dentro das organizações, é alcançada em parte através do pagamento de aluguéis de lealdade corporificados em seus rendimentos. A principal diferença entre a análise conceitual de Goldthorpe e a adotada aqui é, em primeiro lugar, que 
ele não vincula sua análise dos empregos da classe de serviços ao problema da exploração e dos interesses antagônicos e, em segundo, que ele trata a dimensão de autoridade dos cargos gerenciais apenas em termos de responsabilidades maiores, e não de dominação. No entanto, sua conceituação sobre a estrutura de classes usa muitas das mesmas propriedades relacionais a cargos gerenciais e especializados, assim como a conceituação adotada aqui.

Quadro 3: Tipologia de classe mais complexa

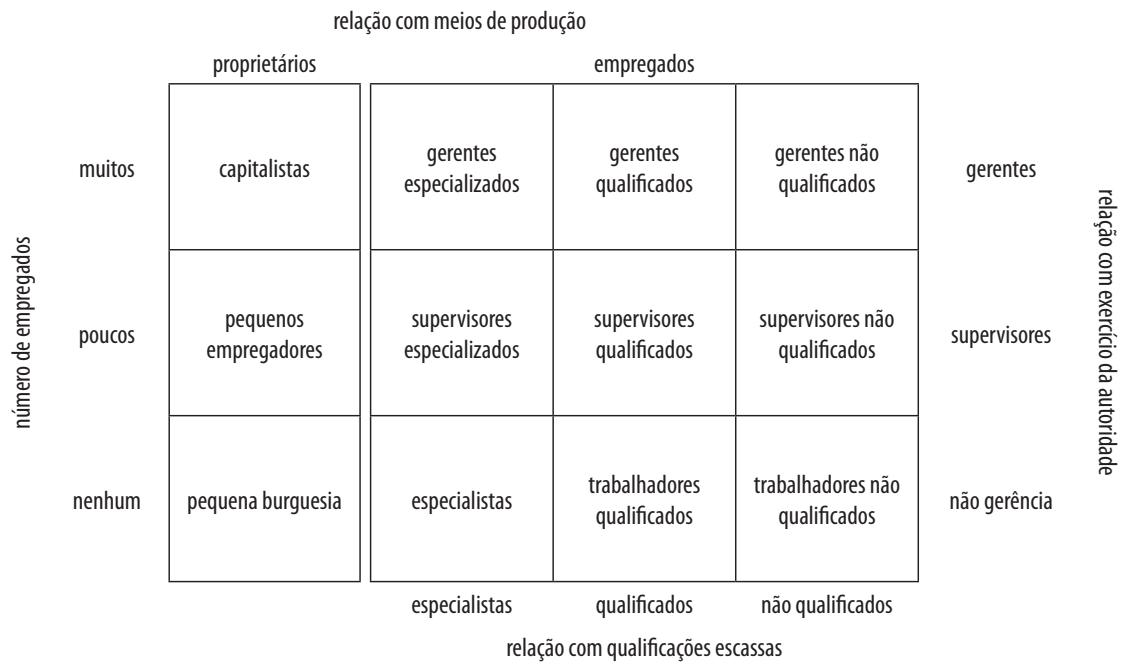

\section{Pessoas que não estão na força de trabalho remunerada}

Muitas pessoas nas sociedades capitalistas - provavelmente a maioria - não têm empregos na força de trabalho paga. O caso mais evidente é o das crianças. Como se devem situar os bebês na estrutura de classes? Mas também há muitas outras categorias: aposentados, deficientes permanentes, estudantes, pessoas que vivem de benefícios da previdência, desempregados e donas de casa em tempo integral ${ }^{30}$. Cada uma dessas categorias de pessoas representa apresenta problemas especiais para a análise da estrutura de classes.

30 A afirmação de que as pessoas nessas categorias não participam diretamente da produção é simples o suficiente para desempregados, aposentados e crianças, mas é problemática para donas de casa, já que estas, obviamente, trabalham e produzem coisas em casa. Isso levou alguns teóricos (por exemplo, Delphy, 1984) a argumentar que o trabalho das donas de casa deve ser tratado como trabalho doméstico realizado dentro de um modo de produção em que elas ocupam uma posição de 
Como aproximação inicial, podemos dividir esse conjunto heterogêneo de situações em duas categorias amplas: as pessoas que estão ligadas à estrutura de classes através das relações familiares e as que não estão. Ocupar uma "posição" dentro da estrutura de classes é ter seus interesses materiais definidos por sua relação com o processo de exploração. Uma maneira em que essas ligações à exploração são geradas pelas estruturas de classe é através dos empregos - o tipo de posição de classe que exploramos até agora. Vou me referir a elas como posições de classe diretas. Mas há outros mecanismos pelos quais as vidas das pessoas estão ligadas ao processo de exploração. Particularmente importantes são as maneiras pelas quais as estruturas familiares e as relações de parentesco ligam os interesses materiais de um indivíduo ao processo de exploração. Nascer em uma família capitalista rica liga a criança aos interesses materiais da classe capitalista via relações familiares. Faz sentido, portanto, dizer que essa criança está "na" classe capitalista. Se, como jovem adulto, ela trabalhar em uma fábrica, mas for herdeira de milhões de dólares em riqueza capitalista e puder contar com os recursos da família para diversas necessidades, ela estará simultaneamente em duas posições de classe: na classe capitalista em virtude dos laços familiares e na classe trabalhadora em virtude do emprego.

Vou me referir a essas situações como posições de classe mediadas. Os laços familiares são provavelmente a base mais importante para as posições de classe mediadas, mas a participação em certos tipos de comunidades ou a relação com o Estado também podem proporcionar essas ligações. Em cada caso, a pergunta a se fazer é "como as relações sociais nas quais a vida de uma pessoa está inserida ligam essa pessoa aos vários mecanismos de exploração de classe e, portanto, moldam seus interesses materiais?" Muitas pessoas, é claro, ocupam posições de classe diretas e mediadas.

classe distinta: a de trabalhadoras domésticas. Outros argumentaram que a produção doméstica é uma parte subsidiária do modo de produção capitalista. Até já se disse (Fraad, Resnick e Wolff, 1994) que a produção doméstica é uma forma especial de produção feudal em que as donas de casa são exploradas de forma feudal por seus maridos, já que estes "se apropriam" diretamente dos valores de uso de suas esposas. Todos esses pontos de vista, de uma forma ou de outra, tentam tratar as relações de gênero e de parentesco dentro de uma família como se fossem um tipo de relações de classe. Essa fusão de classe e gênero fragiliza a especificidade explicativa tanto da primeira quanto do segundo, e não aumenta, em minha opinião, nossa capacidade de explicar os processos em questão. Em todo o caso, como a análise de Class counts é restrita a pessoas que estão na força de trabalho remunerada, vamos colocar de lado essas questões. 
Isso tem particular importância nas economias capitalistas desenvolvidas para famílias em que ambos os cônjuges estão na força de trabalho, pois cria a possibilidade de que maridos e esposas ocupem diferentes posições de classe diretas e, assim, que cada um tenha diferentes posições diretas e mediadas. Compreender essas "famílias interclasse" é o problema central do capítulo 10 de Class counts.

Há, no entanto, pessoas para as quais os laços familiares proporcionam, no máximo, ligações extremamente tênues com a estrutura de classes. O caso mais visível é a situação de muitas pessoas na chamada “subclasse”. Essa expressão é usada de várias maneiras nas discussões políticas contemporâneas. Às vezes, pretende ser um termo pejorativo, um pouco como o velho conceito marxista de "lumpemproletariado"; outras vezes, é usada de forma mais descritiva para designar um segmento dos pobres cujas condições de vida são especialmente desesperadas e cujas perspectivas de melhoria são particularmente sombrias. Nos termos da análise deste texto, uma forma de dar ao conceito um estatuto teórico mais preciso é associá-lo aos conceitos de exploração e opressão: uma "subclasse" pode ser definida como uma categoria de agentes sociais que são economicamente oprimidos, mas não são constantemente explorados dentro de um determinado sistema de classes $^{31}$.

Diferentes tipos de estruturas de classe geram diferentes formas de "subclasse". Em muitas partes do mundo de hoje, e durante a maior parte da história humana, o recurso fundamental que define a subclasse é a terra. Proprietários de terras, capitalistas agrários, camponeses e produtores agrários explorados têm, todos, acesso à terra; as pessoas excluídas desse acesso constituem a subclasse das sociedades agrárias. Nesses termos, muitos índios norte-americanos foram transformados em uma subclasse no século XIX, ao serem expulsos de sua terra para as reservas.

${ }^{31}$ Embora ele não se aprofunde explicitamente no termo "subclasse, em termos de uma teoria da exploração e da opressão econômica, a definição proposta aqui é coerente com os aspectos mais estruturais da forma como o termo é usado por William Julius Wilson $(1982,1987)$ em sua análise da interconexão entre raça e classe na sociedade dos Estados Unidos. Wilson argumenta que, à medida que as barreiras jurídicas à igualdade racial desapareceram e aumentou a diferenciação de classes no seio da população negra, a principal estrutura determinante das vidas de muitos afro-americanos já não é a raça em si, e sim a classe. Mais especificamente, ele afirma que houve um crescimento substancial de uma subclasse urbana de pessoas sem qualificações vendáveis no mercado e com vínculos muito frágeis com a força de trabalho, vivendo em cidades centrais em ruínas, isoladas da vida e das instituições norte-americanas predominantes. 
No capitalismo avançado contemporâneo, o principal recurso que define a difícil situação da subclasse é a própria força de trabalho. Pode parecer uma afirmação estranha, já que, no capitalismo, pelo menos desde a abolição da escravatura, cada pessoa supostamente possui uma "unidade" de força de trabalho. A questão é que algumas pessoas não possuem, de fato, força de trabalho produtivamente vendável. A situação é semelhante à de um capitalista que possua máquinas obsoletas. Embora controle fisicamente essas máquinas, elas deixam de ser "capital” - um ativo capitalista produtivo - se não puderem ser usadas dentro de um processo de produção capitalista de forma lucrativa. No caso da força de trabalho, uma pessoa pode controlar fisicamente sua própria capacidade de trabalho, mas essa capacidade pode deixar de ter valor econômico no capitalismo se não puder ser usada de forma produtiva. Esta é a condição essencial das pessoas situadas na "subclasse". Elas são oprimidas porque não têm acesso a vários tipos de recursos produtivos, principalmente os meios de adquirir as qualificações necessárias para tornar vendável a sua força de trabalho. Como resultado, não são exploradas de forma contínua ${ }^{32}$.

Assim entendida, a subclasse é composta por seres humanos que são, em grande parte, dispensáveis do ponto de vista da lógica do capitalismo. $\mathrm{Da}$ mesmo maneira que com os índios norte-americanos, que se tornaram uma subclasse sem-terra no século XIX, a repressão, em vez da incorporação, é o modo central de controle social direcionado a eles. $\mathrm{O}$ capitalismo não precisa da força de trabalho de jovens desempregados das periferias urbanas. Os interesses materiais dos segmentos ricos e privilegiados da sociedade norte-americana estariam mais bem servidos se essas pessoas simplesmente desaparecessem. No entanto, ao contrário do que acontecia no século XIX, as forças morais e políticas são de tal

32 Talvez seja polêmico fundir a exclusão da subclasse urbana contemporânea em relação ao capital humano e a outros recursos de trabalho com a exclusão de indígenas norte-americanos em relação à terra. Neste último caso, o acesso ao recurso em questão tinha um caráter de soma zero, e se usou coerção maciça para impor a exclusão, ao passo que, no caso de educação, qualificações e até mesmo bons empregos, não é tão óbvio que a quantidade dos recursos em questão seja fixa e que o acesso seja negado por meio da força. Assim, as desigualdades factuais de acesso a esses recursos podem não ser realmente casos de exclusões impostas coercitivamente que beneficiam determinados grupos de pessoas à custa de outros. A difícil situação da subclasse ainda pode ser um motivo de grave preocupação moral, mas não seria um caso de opressão não exploradora, análoga à condição dos índios norte-americanos. 
ordem que o genocídio direto já não é uma estratégia viável, de forma que a alternativa é construir prisões e isolar as zonas das cidades onde vive a subclasse.

\section{A análise de classes marxista comparada com a weberiana}

Como conjunto de categorias empíricas, a matriz da estrutura de classes nos Quadros 2 e 3 poderá ser usada em um referencial weberiano ou em um marxista. O controle dos recursos econômicos é fundamental a ambas as análises de classe, e os dois referenciais podem ser ajustados para permitir a variedade de categorias que estou usando. Na verdade, pode-se argumentar que o conceito de estrutura de classes proposto incorpora elementos weberianos significativos, uma vez que a inclusão explícita de qualificações como critério para a divisão de classes e a importância concedida aos privilégios de renda para gerentes e especialistas diplomados são características de análise de classes weberiana. Em um sentido real, portanto, as categorias empíricas com que trabalho podem ser consideradas um híbrido daquelas convencionalmente encontradas nas análises de classes marxista e weberiana ${ }^{33}$. Em que sentido, portanto, essa análise da estrutura de classes permanece "marxista"?

Para responder a essa pergunta, precisamos comparar os fundamentos teóricos do conceito de classe nas tradições marxista e weberiana ${ }^{34}$. O contraste entre Marx e Weber tem sido um dos grandes temas da história da sociologia como disciplina. A maioria dos programas de pós-graduação tem uma cadeira de teoria sociológica na qual "Marx contra Weber" figura como tema central. No entanto, em termos de análise de classes, apresentar Marx e Weber como polos opostos é um pouco enganador, porque em muitos aspectos Weber usa sua voz mais marxista ao falar de classes. Os conceitos de classe dentro dessas duas correntes de pensamento têm uma série de características importantes em comum:

${ }^{33}$ Ver elementos marxistas e weberianos associados na análise de classes não deveria surpreender tanto. Afinal de contas, a análise de classes de Weber deveu muito ao legado marxista, que fazia parte do discurso intelectual geral de seu tempo. Apesar de Weber ter se distanciado constantemente do marxismo, em particular por causa das inclinações deste ao determinismo econômico, que eram especialmente pronunciadas em sua época, quando fala de classes, ele está falando com uma voz um tanto marxista.

34 Para discussões sobre o contraste entre análises de classe marxista e weberiana, ver, por exemplo, Parkin (1979), Burris (1987), Giddens (1973), Wright (1979, cap. 1). 
- As abordagens marxista e weberiana diferem do que se poderia chamar de noções de classe de gradação simples, em que as classes são diferenciadas estritamente em função das desigualdades nas condições materiais de vida ${ }^{35}$. Essa conceituação de classe corrobora o inventário comum de classes encontrado no discurso popular e nos meios de comunicação de massa: classe alta, classe média alta, classe média, classe média baixa, classe baixa, subclasse. Tanto a análise de classes marxista quanto a weberiana definem relacionalidade, ou seja, uma determinada posição de classe é definida em função das relações sociais que a ligam a outras posições de classe.

- Ambas as tradições identificam o conceito de classe com a relação entre as pessoas e os ativos ou recursos economicamente relevantes. Os marxistas chamam isso de relação com os meios de produção, enquanto os weberianos se referem a "capacidade de mercado", mas, na verdade, ambos estão falando de fenômenos empíricos muito semelhantes.

- As duas tradições consideram que a relevância causal da classe opera, pelo menos em parte, pelas formas nas quais essas relações moldam os interesses materiais dos atores. A propriedade dos meios de produção e a propriedade da própria força de trabalho explicam a ação social, pois esses direitos de propriedade definem as alternativas estratégicas com que as pessoas se deparam na busca de seu bem-estar material. O que as pessoas têm impõe restrições sobre o que elas podem fazer para conseguir o que querem. É claro que os marxistas tendem a dar mais peso ao caráter objetivo desses "interesses materiais" ao destacar o fato de que essas restrições são impostas aos indivíduos, ao passo que os weberianos tendem a se concentrar nas condições subjetivas ao enfatizarem a contingência relativa contida no que as pessoas querem. Não obstante, ainda se pode dizer que, em sua essência, os dois conceitos de classe envolvem a ligação causal entre (a) relações sociais com os recursos e (b) interesses materiais via (c) a forma como os recursos definem estratégias para adquirir renda.

Sendo assim, em que eles diferem? A diferença fundamental é captada pelo contraste entre as expressões favoritas de cada tradição teórica: chances na

${ }^{35}$ O contraste entre os conceitos de classe "graduado" e "relacional" foi introduzido pela primeira vez na sociologia por Ossowski (1963). Para uma discussão mais ampla dos conceitos graduado de classe, ver Wright (1979, cap. 1). 
vida para os weberianos e exploração para os marxistas. A produção é mais central para a análise de classes marxista do que para a weberiana, por sua importância para o problema da exploração; os weberianos dão mais ênfase ao mercado porque ele influencia de forma muito direta as chances na vida.

A intuição por trás da ideia de chances na vida é simples. "Em nossa terminologia”, Weber (em Gerth e Mills, 1958, p. 181-2) escreve:

\footnotetext{
"As classes" não são comunidades; elas representam simplesmente bases possíveis e frequentes para a ação comunitária. Podemos falar de uma classe quando (1) um grupo de pessoas tem em comum um componente causal específico de suas chances na vida, na medida em que esse componente (2) é representado exclusivamente por interesses econômicos na posse de bens e oportunidades de renda e (3) é representado em condições dos mercados de produtos ou de força de trabalho.
}

Esses itens se referem à "situação de classe", que podemos expressar mais brevemente como a típica chance de uma oferta de bens, condições de vida externas e experiências de vida, na medida em que essa oportunidade é determinada pela quantidade e pelo tipo de poder, ou pela falta dele, de dispor de bens ou qualificações que visem renda em uma determinada ordem econômica. O termo "classe" se refere a qualquer grupo de pessoas que se encontre na mesma situação de classe. "Mas esta é sempre a conotação genérica do conceito de classe: de que o tipo de chance no mercado é o momento decisivo que apresenta uma condição comum para o destino do indivíduo. Nesse sentido, 'situação de classe' é, em última análise, 'situação de mercado"' (Weber, em Gerth e Mills, 1958, p. 181-2).

Em suma, o tipo e a quantidade de recursos que alguém possui afetam suas oportunidades para obter renda nas trocas de mercado. "Oportunidade" é uma descrição do conjunto viável que os indivíduos enfrentam, das compensações que encontram para decidir o que fazer. A posse de meios de produção dá a uma pessoa alternativas diferentes de possuir diplomas, e ambas são diferentes de simplesmente possuir força de trabalho não qualificada. Além disso, em uma economia de mercado, o acesso à renda derivada do mercado afeta a gama mais ampla de experiências e oportunidades de vida para si mesmo e para seus filhos. $\mathrm{O}$ estudo das oportunidades de vida dos filhos com base na capacidade de mercado dos pais, portanto, faz parte da agenda weberiana de análise de classes. 
Gráfico 2 - Compensações entre de lazer e consumo por pessoas de diferentes classes econômicas

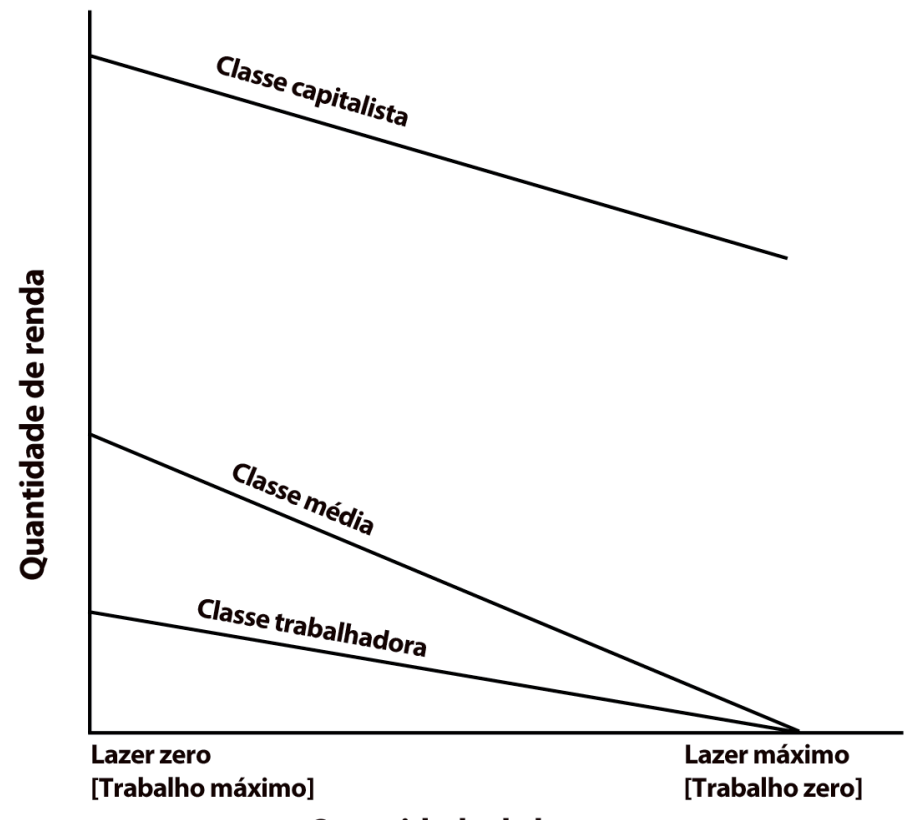

Quantidade de lazer

Em uma perspectiva weberiana, portanto, a questão saliente na ligação das pessoas com diferentes tipos de recursos econômicos é a forma como isso lhes confere diferentes tipos de oportunidades econômicas e desvantagens e, assim, define seus interesses materiais. Uma forma de representar essa ideia de forma simples é examinando os trade-offs entre renda elazer enfrentados pelas pessoas em diferentes classes, conforme indica o Gráfico 2. Segundo a figura, todo mundo enfrenta alguns trade-offs entre lazer e renda: menos lazer gera mais renda ${ }^{36}$. No entanto, para a classe de proprietários, é possível

36 Para simplificar, a compensação entre lazer e consumo é retratada aqui como uma relação linear. Para a classe trabalhadora e a classe média, a inclinação da linha representa, assim, um nível salarial linear. É claro que, no mundo real, em função de aspectos como horas extras, por um lado, e salários abaixo do padrão para o trabalho em meio expediente, por outro, a relação não seria linear. A inclinação da curva de classe capitalista na figura é aproximadamente a mesma da classe média. Se considerarmos todos os capitalistas, e não apenas aqueles com grande talento empreendedor, não há razão para supor a priori que o seu salário atribuído por hora (ou seja, a parte dos seus rendimentos que é derivada do tempo de trabalho, e não de sua propriedade) seria maior do que a da classe média (empregados qualificados e gerentes). De qualquer forma, para os nossos propósitos atuais, a questão principal sobre a curva capitalista é que ela não intersecta o eixo X. 
ter alta renda sem qualquer trabalho (de onde advêm as expressões "classe ociosa" ou "rico indolente"), enquanto, para a classe média e para a classe trabalhadora, nesse esquema, trabalho zero corresponde a lucro zero. A classe média tem "maiores" oportunidades (chances na vida) no mercado do que os trabalhadores porque a inclinação que enfrenta (ou seja, o nível salarial) é mais íngreme. Na verdade, alguns trabalhadores podem ter uma qualidade de vida melhor do que algumas pessoas da classe média, mas os balanços que enfrentam são menos desejáveis. Dessa forma, esses balanços são a base para interesses comuns potenciais entre os membros de uma classe e, assim, constituem a base para uma potencial ação comum. Em um referencial marxista, a característica da relação das pessoas com os recursos econômicos, que está no cerne da análise de classes, é a "exploração". Tanto "exploração" quanto "chances na vida" identificam as desigualdades no bem-estar material que são geradas por desigualdades no acesso a recursos de vários tipos. Então, os dois conceitos apontam para conflitos de interesse sobre a distribuição dos próprios ativos. O que a exploração acrescenta a isso é uma afirmação de que os conflitos de interesses entre as classes são gerados não só pelo que as pessoas têm, mas também pelo que elas fazem com aquilo que têm ${ }^{37}$. O conceito de exploração, portanto, direciona nossa atenção aos conflitos dentro da produção, e não apenas aos conflitos no mercado. Esse contraste entre as tradições marxista e weberiana de análise de classes é resumido no Quadro 4. A análise de classes weberiana gira em torno de um nexo causal único que funciona por meio de trocas de mercado. A análise de classes marxista inclui os processos causais weberianos, mas lhes acrescenta uma estrutura causal dentro da própria produção, bem como uma visão das interações de produção e troca. Parte de nossa análise da posição de classe dos gerentes, por exemplo, refere-se ao "aluguel de lealdade" que eles recebem em função do lugar que ocupam dentro da estrutura de autoridade da produção. Isso reflete a maneira pela qual a posição dentro das relações de produção, e não apenas dentro das relações de mercado, afeta as "chances na vida" dos gerentes. Nossa análise do shmoo - e, mais amplamente, a análise de coisas como

\footnotetext{
${ }^{37}$ A distinção conceitual entre chances na vida e exploração que está sendo discutida aqui vai contra os argumentos de John Roemer (1985), que insiste em que a exploração é estritamente uma maneira de falar sobre a injustiça dos efeitos daquilo que as pessoas têm (ativos) sobre o que elas recebem (renda). Nesse sentido, ele junta o problema da exploração ao problema das chances na vida e, assim, dissolve a distinção entre as análises de classe marxista e weberiana. A noção da extração do esforço de trabalho desaparece da sua análise da exploração.
} 
a forma pela qual os pagamentos feitos pelo estado de bem-estar afetam a capacidade de mercado dos trabalhadores - ilustra como a capacidade do mercado tem um impacto sobre a extração do esforço de trabalho dentro da produção. $\mathrm{O}$ conceito marxista de classe direciona nossa atenção, teórica e empiricamente, a essas interações.

Quadro 4 - Três modelos de análise de classes

I. Análise de classes gradual simples

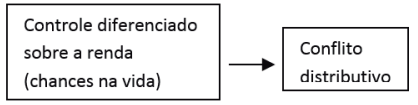

II. Análise de classes weberiana

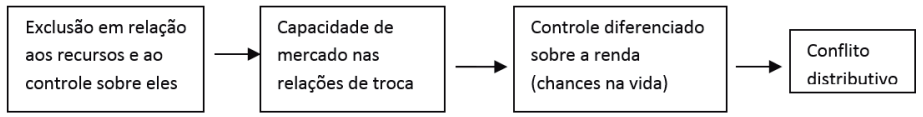

III. Análise de classes marxista

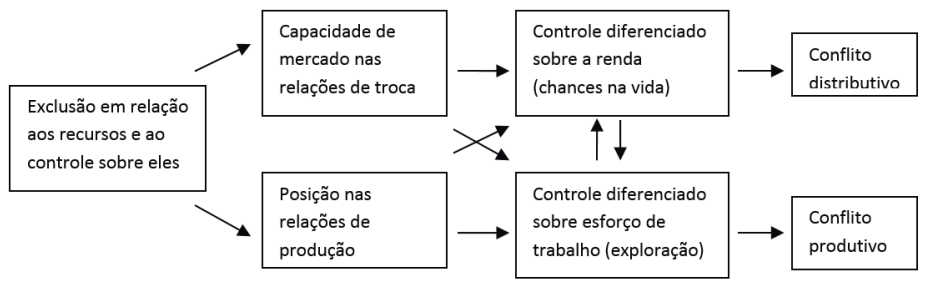

Um weberiano poderia responder que não há nada na ideia weberiana de chances na vida baseadas no mercado que impeça a análise da extração do esforço de trabalho dentro da produção. Um analista de classes weberiano bom e sutil certamente poderia vincular a análise das capacidades de mercado dentro de relações de troca às relações de poder dentro do processo de trabalho e, assim, explorar as estruturas causais que estão no centro da análise de classes marxista. Ao aderir sistematicamente à produção e à troca dessa forma, no entanto, o conceito weberiano se tornaria marxistizado. Frank Parkin (1979, p. 25) disse, em uma famosa ironia: "Dentro de cada neomarxista parece haver um weberiano lutando para sair". Seria possível dizer facilmente que dentro de cada weberiano de esquerda há um marxista lutando para se manter escondido.

Existem três razões principais pelas quais pode ser interessante basear o conceito de classe explicitamente na exploração, e não apenas nas chances na vida baseadas no mercado. 
Em primeiro lugar, o conceito de classe centrado na exploração afirma o fato de que produção e troca estão intrinsecamente ligadas, e não relacionadas apenas de forma contingente. Os interesses materiais de capitalistas e trabalhadores são influenciados inerentemente pela interação dessas duas facetas das relações sociais que os unem. Isso nos permite entender a posição de classe dos gerentes como sendo determinada não apenas pelo lugar que ocupam dentro do mercado de força de trabalho gerencial, mas também por seu lugar nas relações de dominação na produção. De forma mais ampla, o conceito de classe baseado em exploração direciona nossa atenção ao fato de que as relações de classe são relações de poder, e não apenas de privilégio.

Em segundo lugar, teorizar os interesses ligados às classes como sendo baseados em práticas inerentemente antagônicas e interdependentes facilita a análise do conflito social. Explicações do conflito sempre exigem pelo menos dois elementos: uma visão dos interesses opostos em jogo no conflito e outra da capacidade dos atores para ir em busca desses interesses. Uma simples oposição de interesses não é suficiente para explicar o conflito ativo entre grupos. A exploração é um conceito poderoso precisamente porque reúne uma visão de interesses opostos com uma visão da capacidade rudimentar para a resistência. Os exploradores não só têm um interesse concreto em limitar as chances na vida dos explorados, mas também dependem dos explorados para concretizar seus próprios interesses. Essa dependência dos exploradores em relação aos explorados dá a estes uma capacidade inerente para resistir. A exploração, portanto, não prevê apenas uma oposição de interesses, mas também uma tendência desse antagonismo de interesses a gerar conflitos manifestos entre classes. Essa visão do poder inerente das classes exploradas é marginalizada quando se define classe estritamente em termos de relações de mercado.

Por fim, a análise de classes centrada na exploração sugere que as classes possam existir em sociedades que não sejam de mercado, enquanto a análise de classes weberiana restringe explicitamente a relevância da classe aos mercados. Para a análise de classes marxista, a relação entre senhor de escravos e escravo ou entre senhor feudal e servo são casos de relações de classe porque todas envolvem a exploração ligada a direitos de propriedade sobre as forças de produção ${ }^{38}$. A relação entre exploradores burocráticos e

38 A descrição marxista clássica do feudalismo é de uma sociedade em que os senhores feudais se apropriam de produtos excedentes diretamente dos servos usando o que geralmente é chamado 
produtores em economias de comando também pode ser considerada uma forma de relação de classe, já que a capacidade que a elite burocrática do Estado tem de se apropriar do excedente se baseia em seu controle eficaz sobre os recursos produtivos da sociedade (Wright, 1994, cap. 6). Para a análise de classes weberiana, estas não são relações de classe, e sim exemplos de castas ou estamentos, ou de alguma outra forma de desigualdade de poder, uma vez que as diferenças de "chances na vida" entre escravo e senhor de escravos, entre senhor feudal e servo, entre apropriador burocrático e produtor não são resultado de seu encontro dentro de um mercado. A restrição weberiana do conceito de classe a sociedades de mercado, portanto, afasta nossa atenção dos elementos comuns subjacentes a essas relações em diferentes tipos de sistemas sociais.

É claro que não há uma regra metateórica da sociologia que diga que todo sociólogo deve escolher entre uma dessas duas formas para basear a análise de classes. Certamente pode ser possível construir um híbrido eclético entre as análises de classes marxista e weberiana ao se considerar a exploração como definidora das clivagens centrais dentro de uma estrutura de classes e de capacidades de mercado diferenciadas como definidoras de estratos destacados dentro das classes. Os estratos dentro da classe capitalista seriam definidos pela capacidade diferenciada para se apropriar de excedente; os estratos dentro da classe trabalhadora seriam determinados por diferenças de renda e condições de trabalho geradas por diferentes capacidades de mercado. Nesse tipo de análise de classes híbrida, o que eu venho chamando de "classe média" pode ser mais bem descrito como estratos privilegiados dentro da classe trabalhadora.

No entanto, interpretarei a matriz de estrutura de classes que usaremos dentro de um referencial de análise de classes neomarxista. No fim das contas,

de "coerção extraeconômica". Essa coerção passa por forçar o camponês a trabalhar parte da semana na terra do senhor feudal ou exigir alguma parcela do produto do camponês. Outra caracterização possível é dizer que, no feudalismo, o senhor feudal e o servo são coproprietários da força de trabaIho do segundo. Isso dá ao primeiro os direitos de propriedade sobre a capacidade de trabalho do segundo. A escravidão, nesses termos, é simplesmente o caso-limite no qual o escravo perdeu todos os direitos de propriedade sobre sua própria força de trabalho. Essa propriedade conjunta da força de trabalho do servo se reflete nas leis que o vincula à terra e que impedem sua fuga para a cidade. Essa fuga é apenas uma forma de roubo: o servo que foge, assim como o escravo fugitivo, rouba a propriedade do senhor. O uso de coerção extraeconômica, então, é simplesmente o meio para fazer valer esses direitos de propriedade, e não é diferente do uso da coerção extraeconômica para impedir os trabalhadores de assumir o controle de uma fábrica. Para uma discussão mais ampla sobre esse modo de entender o feudalismo, ver Wright (1985, p. 77-8). 
a decisão de fazer isso em vez de adotar uma postura mais eclética resulta, pelo menos em parte, de compromissos políticos, e não simplesmente de princípios científicos imparciais. Isso não significa que a análise de classes marxista seja pura ideologia ou que seja rigidamente ditada por valores igualitários radicais. Minha escolha de referencial analítico também se baseia em minhas crenças na coerência teórica da abordagem - que eu defendi neste texto - e em sua capacidade de esclarecer problemas empíricos, a qual eu busquei demonstrar no restante de Class counts. Mas essa escolha permanece fundamentalmente ligada a compromissos com a tradição socialista e suas aspirações por uma alternativa igualitária e emancipatória ao capitalismo.

Os leitores que forem altamente céticos em relação à tradição marxista, por qualquer motivo, podem considerar que não há sentido em desbravar as grandes quantidades de números, gráficos e equações no restante de Class counts. Se as justificativas conceituais para as categorias forem irremediavelmente falhas, pode-se pensar, os resultados empíricos gerados com essas categorias serão inúteis. Isso me parece um equívoco. As próprias categorias empíricas podem ser interpretadas de uma maneira weberiana ou híbrida. $\mathrm{Na}$ verdade, como um conjunto prático de categorias operacionais, a matriz da estrutura de classes usada aqui não difere muito da tipologia de classe usada por Goldthorpe (1980) e por Erikson e Goldthorpe (1993). Como geralmente acontece em sociologia, as categorias empíricas de análise são subdeterminadas pelos referenciais teóricos em que são geradas ou interpretadas. Isso significa que leitores decididamente não convencidos das virtudes de entender as classes em termos de exploração ainda podem tratar as análises empíricas de Class counts como investigações de classes situadas de forma diferenciada em relação a chances de vida no mercado.

\section{Referências}

AKERLOFF, G. A. \& YELLEN, J. L. (orgs.) (1986). Efficiency wage models of the labor market. Cambridge: Cambridge University Press.

BOURDIEU, Pierre (1984). Distinction: a social critique of the judgement of taste. London; New York: Routledge and Kegan Paul.

BOWLES, Samuel \& GINTIS, Herb (1986). Capitalism and democracy. New York: Basic Books.

(1990). "Contested exchange: new microfoundations for the political economy of capitalism”. Politics \& Society, v. 18, n. 2: 165-222. 
BURRIS, Val (1987). "The neo-marxist synthesis of Marx and Weber on class", em WILEY, N. (org.). The Marx-Weber debate. Newbury Park (CA): Sage Publications.

CAPP, Al (1992). Li'L Abner, v. 14: 1948. Princeton (WI): Kitchen Sink Press. COHEN, G. A. (1978). Karl Marx's theory of history: a defence. Princeton (NJ): Princeton University Press.

(1988). History, labour, and freedom. Oxford: Oxford University Press. DELPHY, Christine (1984). Close to home: a materialist analysis of women's oppression. London: Hutchinson.

ERIKSON, Robert \& GOLDTHORPE, John (1993). The constant flux: a study of class mobility in industrial societies. Oxford: Oxford University Press. FRAAD, Harriet; RESNICK, Stephen \& WOLFF, Richard. (1994). Bringing it all back home: class, gender and power in the modern household. London: Pluto Press.

GIDDENS, Anthony (1973). The class structure of the advanced societies. New York: Harper \& Row.

GERTH, Hans \& C. W. MILLS (1958). From Max Weber. New York: Oxford University Press.

GOLDTHORPE, John (1980). Social mobility and class structure in modern Britain. Oxford: Oxford University Press.

(1982). "On the service class, its formation and future", em GIDDENS, Anthony \& MACKENZIE, Gavin (orgs.). Social class and the division of labour. Cambridge: Cambridge University Press.

OSSOWSKI, Stanislaw (1963). Class structure in the social consciousness. London: Routledge \& Kegan Paul.

PARKIN, Frank (1979). Marxism and class theory: a bourgeois critique. New York: Columbia University Press.

ROEMER, John (1982). A general theory of exploitation and class. Cambridge (MA): Harvard University Press.

(1985). "Should Marxists be interested in exploitation?" Philosophy and Public Affairs, n. 14, p. 30-65.

WILSON, William Julius (1982). The declining significance of race. Chicago: University of Chicago Press.

(1987). The truly disadvantaged. Chicago: University of Chicago Press. WRIGHT, Erik Olin (1979). Class structure and income determination. New York: Academic Press. 
(1985). Classes. London: New Left Books.

(1989). "Rethinking, once again, the concept of class structure", em Erik Olin WRIGHT et al. The debate on classes. London: Verso. (1994). Interrogating inequality. London: Verso.

WRIGHT, Erik Olin; LEVINE, Andrew \& SOBER, Elliott (1992). Reconstructing Marxism: essays on explanation and the theory of history. London: Verso.

\section{Resumo}

No texto, que é o capítulo introdutório do livro Class counts, Wright defende a relevância da análise de classes para o entendimento da sociedade e da política contemporâneas. Ainda que a variável "classe" não explique sozinha todos os fenômenos sociais, nem mesmo seja parte das explicações de todos, ela é significativa em uma grande variedade deles. Portanto, deve ser sistematicamente explorada nas investigações da sociologia e da política. Wright afirma também a superioridade da leitura marxista das classes sociais, capaz de abranger mais facetas do que a weberiana. E, por fim, defende que tal análise deve ter como ponto de partida um entendimento da estrutura de classes, não simplesmente de seus conflitos. Para o desenho desta estrutura, importam a propriedade dos meios de produção, mas também o controle de especializações e de autoridade nas relações de trabalho.

Palavras-chave: classes, marxismo, trabalho

\section{Abstract}

In the text, which is the introductory chapter of the book Class counts, Wright argues for the relevance of class analysis to the understanding of contemporary society and politics. Although the variable "class" alone does not explain all social phenomena and is not part of their explanations, it is significant for a wide variety of them. Therefore, it should be systematically exploited in investigations of sociology and politics. Wright also claims the superiority of the Marxist reading of social classes, which is able to cover more aspects than Weberian reading. And finally, she argues that such analysis must take as its starting point an understanding of the class structure, rather than simply its conflicts. Ownership of means of production matter for the design of that structure, but also control of expertise and authority in labor relations.

Keywords: classes; Marxism; labor 